\title{
Human skin is protected by four functionally and phenotypically discrete populations of resident and recirculating memory $\mathbf{T}$ cells
}

\author{
Rei Watanabe ${ }^{1}$, Ahmed Gehad ${ }^{1}$, Chao Yang ${ }^{1}$, Laura Campbell ${ }^{1}$, Jessica E. Teague ${ }^{1}$, \\ Christoph Schlapbach ${ }^{2}$, Christopher Elco ${ }^{3}$, Victor Huang ${ }^{1}$, Tiago R. Matos ${ }^{1,4}$, Thomas S. \\ Kupper $^{1,5}$, and Rachael A. Clark ${ }^{1,5,6}$
}

${ }^{1}$ Department of Dermatology, Brigham and Women's Hospital, Harvard Medical School, Boston, MA, USA ${ }^{2}$ Department of Dermatology, Inselspital, University of Bern, Bern, Switzerland ${ }^{3}$ Department of Pathology, Brigham and Women's Hospital, Harvard Medical School, Boston, MA, USA ${ }^{4}$ Instituto de Medicina Molecular, Faculdade de Medicina da Universidade de Lisboa, Lisbon, Portugal ${ }^{5}$ Dana-Farber/Brigham and Women's Cancer Center, Boston, Massachusetts

\begin{abstract}
The skin of an adult human contains approximately 20 billion memory T cells. Epithelial barrier tissues are infiltrated by a combination of resident and recirculating $\mathrm{T}$ cells in mice but the relative proportions and functional activities of resident versus recirculating $\mathrm{T}$ cells have not been evaluated in human skin. We discriminated resident from recirculating $\mathrm{T}$ cells in human engrafted mice and lymphoma patients using alemtuzumab, a medication that depletes recirculating $\mathrm{T}$ cells from skin, and then analyzed these $\mathrm{T}$ cell populations in healthy human skin. All non-recirculating resident memory $\mathrm{T}$ cells $\left(\mathrm{T}_{\mathrm{RM}}\right)$ expressed $\mathrm{CD} 69$, but the majority were $\mathrm{CD}^{+}, \mathrm{CD}^{+} 3^{-}$and located in the dermis, in contrast to studies in mice. Both $\mathrm{CD} 4^{+}$and $\mathrm{CD} 8^{+} \mathrm{CD} 103^{+} \mathrm{T}_{\mathrm{RM}}$ were enriched in the epidermis, had potent effector functions and had a limited proliferative capacity compared to $\mathrm{CD}_{103^{-}} \mathrm{T}_{\mathrm{RM}}$. $\mathrm{T}_{\mathrm{RM}}$ of both types had more potent effector functions than recirculating T cells. Induction of CD103 on human T cells was enhanced by keratinocyte contact, depended on TGF $\beta$ and was independent of T cell keratinocyte adhesive interactions. We observed two distinct populations of recirculating $\mathrm{T}$ cells, $\mathrm{CCR} 7^{+} / \mathrm{L}$-selectin ${ }^{+}$central memory $\mathrm{T}$ cells $\left(\mathrm{T}_{\mathrm{CM}}\right)$ and $\mathrm{CCR} 7^{+} / \mathrm{L}$-selectin ${ }^{-} \mathrm{T}$ cells, which we term migratory memory $\mathrm{T}$ cells $\left(\mathrm{T}_{\mathrm{MM}}\right)$. Circulating skin-tropic $\mathrm{T}_{\mathrm{MM}}$ were intermediate in cytokine production between $\mathrm{T}_{\mathrm{CM}}$ and effector memory $\mathrm{T}$ cells. In patients with cutaneous $\mathrm{T}$ cell lymphoma, malignant $\mathrm{T}_{\mathrm{CM}}$ and $\mathrm{T}_{\mathrm{MM}}$ induced distinct inflammatory skin lesions and $\mathrm{T}_{\mathrm{MM}}$ were depleted more slowly from skin after alemtuzumab, suggesting $\mathrm{T}_{\mathrm{MM}}$ may recirculate more slowly. In summary, human skin is protected by four
\end{abstract}

\footnotetext{
${ }^{6}$ Correspondence should be addressed to: Rachael A. Clark, Department of Dermatology, Brigham and Women's Hospital, Room 505A, 221 Longwood Avenue, Boston, Massachusetts 02115. Phone (617) 525-5552; Fax (617) 525-5571; rclark1 @ partners.org. Author contributions: R.A.C. planned and supervised experiments, analyzed data, prepared figures and drafted the manuscript. R.W planned and carried out experiments, analyzed data, carried out statistical analyses, prepared figures and provided clinical data. A.G., C.Y., L.C.,J.E.T., C.S., T.M. and V.H. assisted in carrying out experiments and J.E.T. also provided editorial assistance. C.E. assisted in preparing figures. T.S.K. provided CTCL patient samples and advice on experimental approaches.

Competing interests: The authors declare that they have no competing interests.
} 
functionally distinct populations of $\mathrm{T}$ cells, two resident and two recirculating, with differing territories of migration and distinct functional activities.

\section{Introduction}

Research in both mice and humans has confirmed that skin and other epithelial barrier tissues are populated by a combination of non-recirculating resident memory cells $\left(\mathrm{T}_{\mathrm{RM}}\right)$ as well as $\mathrm{T}$ cells that recirculate in and out of tissues $(1,2)$. However, the relative proportions and functional activities of resident and recirculating $\mathrm{T}$ cells in skin have never been comprehensively studied, especially in humans. $\mathrm{T}_{\mathrm{RM}}$ cause psoriasis and mycosis fungoides and are implicated in a variety of other human autoimmune and inflammatory conditions (3). A better understanding of resident and recirculating $\mathrm{T}$ cells could lead to novel therapies for $\mathrm{T}$ cell mediated inflammatory diseases.

Our prior studies of patients with cutaneous T-cell lymphoma (CTCL) found that treatment with alemtuzumab, a humanized anti-CD52 antibody, depleted all circulating T cells and purged the skin over time of recirculating $\mathrm{T}$ cells but spared a population of nonrecirculating $\mathrm{T}_{\mathrm{RM}}$ in the skin (2). Alemtuzumab depletes $\mathrm{T}$ cells in the blood stream but not in the skin because it depletes by antibody dependent cellular cytotoxicity (ADCC) requiring the presence of neutrophils and/or NK cells, cell types that are rare in human peripheral tissues such as the skin but frequent in the circulation $(2,4)$.

In these studies, we have studied resident and recirculating $\mathrm{T}$ cell subsets in a human engrafted mouse model and in human patients with CTCL, utilizing alemtuzumab as a tool to deplete recirculating $\mathrm{T}$ cells from skin. This has allowed us to discriminate between resident and recirculating $\mathrm{T}$ cell populations in human skin and to study their relative frequencies and effector functions. We find that human skin is protected by two distinct populations of recirculating $\mathrm{T}$ cells and two distinct populations of resident memory $\mathrm{T}$ cells, each with different functional capacities.

\section{RESULTS}

\section{Skin T cells in a human engrafted mouse model recapitulate $T$ cell populations in healthy human skin}

In order to selectively study recirculating and resident $\mathrm{T}$ cells in human skin in an accessible model, we grafted NSG mice with human neonatal foreskin, infused them IV with allogeneic PBMC, allowed a dermatitis to develop and then treated these mice with alemtuzumab to deplete recirculating $\mathrm{T}$ cells from skin (Fig. 1A). Neonatal foreskin was used in these studies because, based on mouse studies showing that $\mathrm{T}_{\mathrm{RM}}$ are generated in skin following cutaneous infections, we suspected neonatal human foreskin would have few resident memory $\mathrm{T}$ cells $(1,5,6)$. This was in fact the case. Human neonatal foreskin contained resident antigen presenting cells (APC) including $\mathrm{CD}_{1} \mathrm{a}^{+}$Langerhans cells and CD11 ${ }^{+}$dendritic cells (DC, Fig. 1B,C) but had very few T cells (Fig. 1C,D). There were four-fold more CD11 $\mathrm{c}^{+}$DC than T cells in neonatal foreskin (Fig. 1C) and 45-fold fewer $\mathrm{T}$ cells in foreskin than in healthy adult human skin (Fig. 1D). Additionally, T cells isolated 
from foreskin lacked expression of the $\mathrm{T}_{\mathrm{RM}}$ markers CD69 and CD103, which were robustly expressed by a subset of $\mathrm{T}$ cells from adult human skin (Fig. 1E). Neonatal foreskin was therefore a excellent source of $\mathrm{T}$ cell depleted human skin in which the migration and differentiation of newly generated $\mathrm{T}_{\mathrm{RM}}$ could be studied. Allogeneic $\mathrm{T}$ cells injected IV into grafted mice migrated specifically into the human skin graft and educed an inflammatory dermatitis characterized by migration of $\mathrm{T}$ cells into both the dermis and epidermis (Fig. 1F$\mathrm{H})$. In contrast, mice grafted with human foreskin but not injected i.v. with allogeneic T cells lacked inflammation (Fig. 1I). T cells were evident within the graft by week 1 after infusion and the $\mathrm{T}$ cell infiltrate was maximal by week 3 (Supp. Fig. 1). In mice, $\mathrm{T}_{\mathrm{RM}}$ generated by viral infections with HSV and vaccinia virus co-expressed CD69 and CD103 (5, 6). A subset of T cells infiltrating the human skin graft up-regulated CD69 and CD103 after migration into the graft (Fig. 1J). CD69 was expressed within in the first week after T cell entry into the graft but up-regulation of CD103 was slower and peaked at week three (Fig. 1J). We compared the $\mathrm{T}$ cells in foreskin grafts with those isolated from healthy adult human skin, a tissue known to contain both skin-tropic $\mathrm{CCR} 7^{+} / \mathrm{L}$-selectin ${ }^{+}$central memory cells $\left(\mathrm{T}_{\mathrm{CM}}\right)$ and non-recirculating $\mathrm{T}_{\mathrm{RM}}(2,7)$. Grafts from mice contained CCR $7^{+} / \mathrm{L}$-selectin ${ }^{+}$skin tropic $\mathrm{T}$ and $\mathrm{T}_{\mathrm{CM}}$ cells that expressed CD69 and CD103 in proportions similar to those isolated from antigen-experienced adult human skin (Fig. 1K). A population of $\mathrm{CD}^{2} 9^{+} \mathrm{T}$ cells that lacked CD103 expression, a subset not reported in mice, was also observed in skin grafts and in healthy human skin (Fig. 1K). The percentages of T cells expressing CD69 and CD103 in the grafted skin was not significantly different from the percentages expressed by $\mathrm{T}$ cells from healthy adult human skin (Fig. 1L).

\section{Alemtuzumab depletes recirculating $T_{C M}$ from skin grafts but spares a population of $T$ cells in skin}

Our previous studies in human CTCL patients treated with alemtuzumab demonstrated that this medication depleted $\mathrm{T}$ cells in blood and purged the skin of recirculating $\mathrm{T}$ cells over time but spared a population of non-recirculating resident memory T cells in skin (2). Similar to our results in CTCL patients, treatment of foreskin-grafted, PBMC-injected mice with alemtuzumab depleted circulating $\mathrm{T}$ cells from the blood but spared a subpopulation of T cells in skin (Fig. 2A,B). In contrast, A-dmDT(390)-bisFv(UCHT1), a recombinant immunotoxin composed of diphtheria toxin conjugated to anti-CD3, completely depleted $\mathrm{T}$ cells in both blood and skin (Fig. 2A,B). In CTCL patients, alemtuzumab depleted the skin of recirculating $\mathrm{CCR} 7^{+} / \mathrm{L}$-selectin ${ }^{+} /$central memory $\mathrm{T}$ cells $\left(\mathrm{T}_{\mathrm{CM}}\right)$, a population that is also observed in healthy skin $(2,7)$. Likewise, alemtuzumab depleted both $\mathrm{CD}^{+}$and $\mathrm{CD} 8^{+} \mathrm{T}_{\mathrm{CM}}$ from skin grafts on human engrafted mice (Fig. 2C,D).

\section{Distinct populations of non-recirculating $T_{R M}$ exist in human engrafted mice and human skin}

Having established that the cell populations in human engrafted mice were comparable to those in healthy human skin and that alemtuzumab depleted recirculating $\mathrm{T}$ cells in this model as it did in human patients (Figs.1,2), we set out to study the non-recirculating $\mathrm{T}_{\mathrm{RM}}$ populations left within the human skin grafts after alemtuzumab treatment. The vast majority of $T_{\mathrm{RM}}$ remaining in skin after alemtuzumab depletion of recirculating $\mathrm{T}$ cells expressed $\mathrm{CD} 9^{+}$and a subset coexpressed CD103 (Fig. 3A). In human engrafted mice, 
$\mathrm{CD} 4^{+} \mathrm{T}$ cells were four-fold more frequent than $\mathrm{CD} 8^{+} \mathrm{T}$ cells both before and after depletion of recirculating $T$ cells with alemtuzumab, suggesting that CD4 cells predominated in both the recirculating and resident $\mathrm{T}$ cell populations in this model (Fig. 3B). Approximately half of $\mathrm{CD} 8^{+} \mathrm{T}_{\mathrm{RM}}$ expressed CD103 but the majority of $\mathrm{CD} 4^{+} \mathrm{T}_{\mathrm{RM}}$ did not (Fig. 3C). When $\mathrm{T}_{\mathrm{RM}}$ were evaluated as a whole, the most frequent population were $\mathrm{CD}^{+}{ }^{+} \mathrm{CD} 103^{-} \mathrm{T}$ cells, which made up approximately $66 \%$ of the total $\mathrm{T}_{\mathrm{RM}}$ population (Fig. 3D). $\mathrm{CD}^{+} \mathrm{T}$ cells made up $17 \%$ of the $\mathrm{T}_{\mathrm{RM}}$ population and only $26 \%$ of the total $\mathrm{T}_{\mathrm{RM}}$ population expressed CD103. CD69+ $\mathrm{T}$ cells were evident in both the epidermis and dermis of grafts from alemtuzumab treated human engrafted mice and only a subset of these $\mathrm{T}$ cells, in both the epidermis and the dermis, coexpressed CD103 (Fig. 3E). In order to confirm these results in human patients, we studied the T cells remaining in the skin of CTCL patients after alemtuzumab therapy. We found that, similar to results in human engrafted mice, $\mathrm{T}_{\mathrm{RM}}$ remaining in skin after alemtuzumab virtually all expressed CD69 and a subset of both CD4 and CD8 T cells co-expressed CD103 (Fig. 3F). In addition, a small population of L-selectin ${ }^{+} \mathrm{CCR} 7^{-}$existed in human engrafted mice, healthy skin, and the skin of CTCL patients (Figs. 2C, S3A, E-F). These cells were not depleted by alemtuzumab and coexpressed CD69, suggesting they are $\mathrm{T}_{\mathrm{RM}}$ (Figs. 2C, S3A, E-F).

\section{Antigen experienced human skin contains two phenotypically and functionally distinct populations of $\mathrm{T}_{\mathrm{RM}}$}

Studies in human engrafted mice and alemtuzumab treated CTCL patients demonstrated there were two distinct populations of $\mathrm{CD} 9^{+}$non-recirculating $\mathrm{T}_{\mathrm{RM}}$ in skin, one that expressed CD103 and one that did not. However, the relative percentages and effector functions of cells in the mouse model and in patients with a Th2 biased T-cell lymphoma were unlikely to reflect those observed in healthy human skin (8-11). We therefore extracted and studied the $\mathrm{T}$ cells from healthy adult human skin, a tissue in which $\mathrm{T}_{\mathrm{RM}}$ have presumably accumulated over many years of infections and antigen exposures.

In mouse skin, the most frequently observed and well described $\mathrm{T}_{\mathrm{RM}}$ subset are intraepithelial $\mathrm{CD} 8^{+} \mathrm{CD} 103^{+} \mathrm{T}$ cells and $\mathrm{T}$ cells of this phenotype have also been observed after HSV infection in humans $(5,6,12,13)$. In order to study the location and proportion of $\mathrm{T}_{\mathrm{RM}}$ in human skin, we enzymatically split skin into epidermis and dermis and isolated the $\mathrm{T}$ cell populations by collagenase digestion (Fig $4 \mathrm{~A}-\mathrm{C}$ ). $\mathrm{CD}^{+}$and $\mathrm{CD} 8^{+} \mathrm{T}$ cells coexpressing CD69 and $\mathrm{CD}_{103^{+}}$were evident in both the epidermis and the dermis, although $\mathrm{CD} 103^{+} \mathrm{T}_{\mathrm{RM}}$ of both subsets were more frequent in the epidermis. $\mathrm{CD} 69^{+} \mathrm{CD} 103^{-} \mathrm{T}_{\mathrm{RM}}$ were more prevalent in the dermis and both $\mathrm{CD} 4^{+}$and $\mathrm{CD} 8^{+} \mathrm{T}$ cells had this phenotype. $\mathrm{CD}^{-} 9^{-} \mathrm{T}$ cells, referred to as recirculating $\mathrm{T}$ cells, were the least frequent $\mathrm{T}$ cell population in both the epidermis and the dermis (Fig. 4B,C).

We next studied the functional capacities of $\mathrm{T}_{\mathrm{RM}}$ and recirculating subsets from whole skin, epidermis and dermis. In general, cytokine production by the two distinct $\mathrm{T}_{\mathrm{RM}}$ subsets was greater than observed in recirculating $\mathrm{T}$ cells, consistent with their role as resident immune sentinels (Fig. 4D). Effector cytokine production by $\mathrm{CD} 103^{+} \mathrm{T}_{\mathrm{RM}}$ also tended to be more robust than in $\mathrm{CD}_{103^{-}} \mathrm{T}_{\mathrm{RM}}$, most notably with respect to production of IFN $\gamma, \mathrm{TNFa}$ and IL-22. Taken together, these results demonstrate that two phenotypically and functionally 
distinct populations of $\mathrm{T}_{\mathrm{RM}}$ exist in both the $\mathrm{CD} 4^{+}$and $\mathrm{CD} 8^{+} \mathrm{T}$ cell compartments in human skin. $\mathrm{CD} 103^{+} \mathrm{T}$ cells were enriched in the epidermis and had a tendency for increased effector cytokine production, whereas $\mathrm{CD}_{103^{-}} \mathrm{T}_{\mathrm{RM}}$ were more frequent in the dermis and had slightly lower but still very potent effector functions when compared to recirculating $\mathrm{T}$ cells.

In order to study the relative proliferative capacity of the two $\mathrm{T}_{\mathrm{RM}}$ subsets in healthy skin, we first isolated $\mathrm{T}$ cells from the epidermis and dermis as CD103 enriched and depleted populations respectively. T cells isolated from the epidermis retained CD103 expression but rapidly lost functional activity and underwent apoptosis after removal from the skin environment, similar to the behavior of $\mathrm{CD}_{103^{+}} \mathrm{T}_{\mathrm{RM}}$ isolated from mouse brain after infection with vesicular stomatitis virus (14) (Fig. S2A-E). In order to study antigen responses and proliferative capacity without removing $\mathrm{T}$ cells from skin, we injected stimulatory anti-CD3 and anti-CD28 antibodies or antigen derived from heat killed Candida albicans or Staphylococcus aureus directly into explants of human skin. Injected skin explants were cultured for 2 weeks after which T cells were collected. Proliferation was assayed by staining for Ki-67 and cytokine production was assayed by intracellular flow cytometry following short-term stimulation with PMA and ionomycin (Fig. 5). In both $\mathrm{CD}^{+}$and $\mathrm{CD} 8^{+} \mathrm{T}$ cells, proliferation was greatest in the $\mathrm{CD} 103^{-} \mathrm{T}_{\mathrm{RM}}$ subset in response to both antibody and antigen stimulation, although differences only reached significance in $\mathrm{CD}^{+} \mathrm{T}$ cells (Fig. 5A,C). Production of TNFa tended to be greater in the CD103 ${ }^{+}$ population (Fig. 5B,D). Taken together, these studies suggest that $\mathrm{CD}_{103^{+}} \mathrm{T}_{\mathrm{RM}}$ had superior effector functions but a limited proliferative capacity.

\section{T cell CD103 induction is enhanced by keratinocyte contact, depends on TGF $\beta$ and is independent of $\mathrm{T}$ cell keratinocyte adhesion}

In mouse models of viral skin infection, $\mathrm{CD} 103$ expression by $\mathrm{T}$ cells required entry into the epidermis and depended on $\operatorname{TGF} \beta(15,16)$. In human engrafted mice, $\mathrm{T}$ cells that had migrated into the epidermis had a higher rate of CD103 positivity than dermal $\mathrm{T}$ cells (Fig. 6A,B). To determine if keratinocyte contact can induce human $\mathrm{T}$ cell CD103 upregulation, we cultured $\mathrm{T}$ cells stimulated with $\mathrm{aCD} 3 / \mathrm{aCD} 2 / \mathrm{aCD} 28$ beads on keratinocyte or fibroblasts monolayers either in direct contact or separated by transwells. CD103 upregulation was enhanced by direct contact with keratinocytes (Fig. 6C). To determine if adhesive interactions between $\mathrm{T}$ cells and keratinocytes participated in the signaling required for induction of CD103, we included function blocking antibodies against E-cadherin, LFA-1 and $\beta 1$ integrins in T cell and keratinocyte monolayer cultures (Fig. 6D). Blocking adhesive interactions had no effect on CD103 upregulation but neutralizing antibodies against TGF $\beta$ decreased CD103 induction. Additional studies in transwells and in direct cocultures demonstrated that neutralization of TGF $\beta$ decreased the CD103 upregulation induced by keratinocyte contact and that recombinant human TGF $\beta$ markedly increased CD103 induction in both the presence and absence of contact with keratinocytes (Fig. 6E,F). Although adhesive interactions between keratinocyte E-cadherin and CD103 did not participate in stimulating CD103 induction, these interactions did function to anchor T cells to keratinocyte monolayers. 


\section{Human skin also contains two distinct populations of recirculating memory $\mathrm{T}$ cells}

We had previously reported that healthy human skin was patrolled by a skin tropic population of central memory $\mathrm{T}$ cells that co-expressed both skin homing receptors (CLA/ CCR4) and central memory markers (CCR7/L-selectin) and were depleted by alemtuzumab therapy (2). However, when reviewing our results, we observed that both healthy skin and the skin of CTCL patients contained a distinct population of CCR $7^{+} / \mathrm{L}$-selectin ${ }^{-} \mathrm{T}$ cells (Fig. 7A,B). CCR $7^{+} / \mathrm{L}$-selectin ${ }^{-} \mathrm{T}$ cells were confined to the dermis and absent from the epidermis (Fig. S3A). Approximately a third of CCR $7^{+} / \mathrm{L}_{-}$-selectin ${ }^{-} \mathrm{T}$ cells co-expressed CD69, suggesting they may be $\mathrm{T}$ cells in a transitional state, but the remaining CCR $7^{+} / \mathrm{L}$ selectin ${ }^{-} / \mathrm{CD}^{-} 9^{-} \mathrm{T}$ cells made up a significant proportion of $\mathrm{T}$ cells in both healthy skin and in CTCL patients (Fig. 7B). These T cells were depleted in CTCL patients by alemtuzumab therapy, demonstrating that they represent a recirculating $\mathrm{T}$ cell population (Fig. 7A,B). In mice, CCR7 expression is required for exit from peripheral tissues via lymphatics and a recirculating population of $\mathrm{CD} 4^{+} / \mathrm{CCR} 7^{+} / \mathrm{L}$-selectin ${ }^{\text {lo }} \mathrm{T}$ cells was found in Kaede mice to recirculate out of skin in a CCR7-dependent manner (17-19). CCR7 $7^{+} / \mathrm{L}_{-}$selectin ${ }^{-}$cells, which we will refer to as migratory memory $\mathrm{T}$ cells $\left(\mathrm{T}_{\mathrm{MM}}\right)$, were present in similar proportions in both healthy skin and among the benign, nonmalignant $\mathrm{T}$ cells in patients with CTCL and these cells were completely depleted by alemtuzumab therapy (Fig. 7B). $\mathrm{T}_{\mathrm{MM}}$ made up the majority of both $\mathrm{CD}^{+}$and $\mathrm{CD} 8^{+} \mathrm{CLA}^{+}$skin tropic $\mathrm{T}$ cells in the blood of healthy human donors, confirming that $\mathrm{T}$ cells do recirculate between the blood and skin (Fig. 7C, representative histograms in Fig. S4). We next isolated skin tropic $\left(\mathrm{CLA}^{+}\right) \mathrm{T}_{\mathrm{CM}}$, $\mathrm{T}_{\mathrm{MM}}$ and effector memory $\mathrm{T}$ cells $\left(\mathrm{T}_{\mathrm{EM}}\right)$ from human blood and compared their relative functional capacities after stimulation with PMA and ionomycin followed by comprehensive cellular phenotype by CyTOF mass cytometry (Fig. 7D). In general, effector cytokine production by $\mathrm{T}_{\mathrm{MM}}$ was intermediate between that of $\mathrm{T}_{\mathrm{EM}}$ and $\mathrm{T}_{\mathrm{CM}}$. Interestingly, production of Th1, Th17 and Th22 proinflammatory effector cytokines was highest in $\mathrm{T}_{\mathrm{EM}}$, but Th2 cytokine production (IL-4 and IL-13) was highest in $\mathrm{T}_{\mathrm{CM}}$. TNFa was produced at high levels by all $\mathrm{T}$ cell subsets. Although not significantly different, IL-2 production, previously reported as a feature of $\mathrm{T}_{\mathrm{CM}}$ that may render them resistance to apoptosis, tended to be higher in the recirculating $\mathrm{T}_{\mathrm{CM}}$ and $\mathrm{T}_{\mathrm{MM}}$ populations than in $\mathrm{T}_{\mathrm{EM}}$ (20).

\section{$\mathrm{T}_{\mathrm{MM}}$ are associated with the development of expanding skin lesions in patients with $\mathrm{CTCL}$ and are depleted from skin more slowly than $\mathrm{T}_{\mathrm{CM}}$}

$\mathrm{CLA}^{+}$skin tropic CCR7 $7^{+} / \mathrm{L}_{-}$selectin ${ }^{-} \mathrm{T}_{\mathrm{MM}}$ clearly recirculate between human blood and skin, as evidenced by their presence in both sites and their depletion by alemtuzumab in patients with CTCL. $\mathrm{T}_{\mathrm{MM}}$ leaving skin via the lymphatics would be expected to enter skin draining lymph nodes and eventually re-enter the circulation via the thoracic duct. However, these cells lack L-selectin and likely cannot access lymph nodes from blood the way naïve $\mathrm{T}$ cells and $\mathrm{T}_{\mathrm{CM}}$ are thought to, by migrating across high endothelial venues $(21,22)$. Instead, these $\mathrm{T}$ cells would be expected to home directly back to skin. In order to study the biologic behavior of these cells in human beings in vivo, we studied CTCL patients with malignant $T$ cells that expressed markers of $\mathrm{T}_{\mathrm{MM}}$. We have previously observed that patients with classic Sézary syndrome, composed of the clinical triad of diffuse erythema of the skin, enlargement of the lymph nodes draining both skin and other organs and circulating malignant $\mathrm{T}$ cells in the blood, have malignant $\mathrm{T}$ cells with the phenotype of skin tropic 
central memory $\mathrm{T}$ cells $(2,23)$. CLA ${ }^{+} \mathrm{T}_{\mathrm{CM}}$ would be expected to recirculate between the skin, blood and lymph nodes according to our current understanding of trafficking, and this is precisely where malignant $\mathrm{T}$ cells accumulate in Sézary patients. Moreover, we found that malignant $\mathrm{T}$ cells of a CLA ${ }^{+} \mathrm{T}_{\mathrm{CM}}$ phenotype induced in patients a diffuse erythema of the skin, and that this diffuse erythema was the best clinical predictor of complete remission in response to alemtuzumab therapy (Fig. 8A)(24). However, patients have a myriad of clinical presentations and we have found that some patients present with erythematous skin lesions that have ill-defined borders, in contrast to patients with Sézary syndrome, who present with diffuse erythema, and patients with mycosis fungoides (MF), who present with fixed, recurrent and sharply demarcated inflammatory skin lesions (Fig. 8). We found that patients with malignant $\mathrm{T}$ cells that had the phenotype of $\mathrm{CCR} 7^{+} / \mathrm{L}$-selectin ${ }^{-} \mathrm{T}_{\mathrm{MM}}$ tended to have only involvement of the lymph nodes draining the skin and to have expanding inflammatory skin lesions with ill-defined borders. (Fig. 8B-D). In one patient, the malignant $\mathrm{T}$ cells in blood and skin were a combination of both $\mathrm{T}_{\mathrm{CM}}$ and $\mathrm{T}_{\mathrm{MM}}$. This patient had a background of diffuse erythema as well as more discrete skin lesions on presentation (Figure 8E). After 18 days on alemtuzumab, re-biopsy of the skin demonstrated that $\mathrm{T}_{\mathrm{CM}}$ had been partially depleted but large numbers of $\mathrm{T}_{\mathrm{MM}}$ remained in the skin. This was associated with resolution of the diffuse erythema but persistence of the erythematous skin lesions. Taken together, the lack of lymph node disease, the clinical appearance of these lesions and the fact that $\mathrm{T}_{\mathrm{CM}}$ were depleted more rapidly from the skin then $\mathrm{T}_{\mathrm{MM}}$ after alemtuzumab therapy suggest that $\mathrm{T}_{\mathrm{MM}}$ do recirculate between the blood and skin, are excluded from the lymph nodes, and may recirculate more slowly than $\mathrm{T}_{\mathrm{CM}}$.

\section{Discussion}

The skin surface of a healthy adult human being contains nearly 20 billion diverse memory $\mathrm{T}$ cells with potent effector functions (7). Our previous studies in alemtuzumab treated CTCL patients demonstrated that human skin contains a combination of resident and recirculating memory $\mathrm{T}$ cells but the relative frequencies and functional activities of the subsets remain uncharacterized (2). In the current studies, we used alemtuzumab as a tool to deplete recirculating $\mathrm{T}$ cells from skin in order to discriminate between recirculating and resident memory $\mathrm{T}$ cell populations.

We developed a human engrafted mouse model to study human resident and recirculating $\mathrm{T}$ cell populations in skin. Immunodeficient mice were grafted with human neonatal foreskin, a tissue that contains resident Langerhans cells and DC but has few T cells. The paucity of resident $\mathrm{T}$ cells in the graft allowed us to be more confident that $\mathrm{T}$ cells observed in the skin after allogeneic i.v. PBMC infusion were derived from the i.v. injected $\mathrm{T}$ cells. $\mathrm{T}_{\mathrm{RM}}$ are normally generated as a result of cutaneous infections. We took advantage of the fact that graft resident APC were likely to activate T cells migrating into the graft from the blood via direct allo-recognition, a direct recognition of MHC I and II by allogeneic CD8 ${ }^{+}$and CD4 ${ }^{+}$ $\mathrm{T}$ cells, respectively. Direct allo-recognition induces a robust polyclonal $\mathrm{T}$ cell response, engaging up to $10 \%$ of $\mathrm{T}$ cells (25). In other words, we utilized the allogeneic $\mathrm{T}$ cell response to engage the $\mathrm{T}$ cell receptor and initiate the $\mathrm{T}_{\mathrm{RM}}$ differentiation program within grafted skin. We observed the development of $\mathrm{CD} 9^{+}$and $\mathrm{CD} 103^{+} \mathrm{T}$ cells in grafted skin in proportions that were similar to those in adult human skin. However, antigen recognition of 
allogeneic tissues is likely ongoing in human engrafted mice and some $\mathrm{CD}_{103^{-}} \mathrm{T}$ cells may be in the process of transitioning to $\mathrm{CD} 103^{+} \mathrm{T}_{\mathrm{RM}}$.

We next treated these mice with alemtuzumab in order to discriminate between recirculating and resident memory $\mathrm{T}$ cell subsets. Similar to our previous results in CTCL patients treated with alemtuzumab, alemtuzumab purged the skin of recirculating $\mathrm{T}_{\mathrm{CM}}$ but spared a population of T cells in skin. In contrast, immunotoxin A-dmDT (390)-bisFv(UCHT1), an anti-CD3 recombinant diphtheria immunotoxin currently in trials for the treatment of CTCL, depleted $\mathrm{T}$ cells completely in both blood and skin of grafted mice (26).

We observed that virtually all $\mathrm{T}$ cells remaining in the skin of grafted mice following alemtuzumab expressed CD69 and similar results were observed in alemtuzumab treated CTCL patients. In mice, nonrecirculating $\mathrm{T}_{\mathrm{RM}}$ generated from experimental infections expressed CD69 and populations of T cells in human peripheral tissues have been shown to express this marker as well $(1,7,27)$. CD69 suppresses the activity of sphingosine 1 phosphate receptor 1 (S1P1) and S1P1 down-regulation in mice was found to be necessary for retention of $\mathrm{CD}^{+} \mathrm{T}_{\mathrm{RM}}$ in skin $(16,28)$. However, it has never been conclusively demonstrated in humans that CD69 identifies the non-recirculating $\mathrm{T}$ cell pool in peripheral tissues. Our studies in human engrafted mice and in human patients treated with alemtuzumab demonstrate that CD69 is an excellent marker for nonrecirculating $\mathrm{T}_{\mathrm{RM}}$ in human skin.

Most of the $\mathrm{T}_{\mathrm{RM}}$ generated by viral infections in mice are sessile $\mathrm{CD} 8^{+} \mathrm{T}$ cells expressing CD69 and CD103 localized to the epithelium, although dermal CD4 ${ }^{+} \mathrm{T}_{\mathrm{RM}}$ with more mobility have also been observed following HSV infection $(1,5,6,29)$. Our studies in engrafted mice, CTCL patients and healthy human skin demonstrate that the majority of human skin $\mathrm{T}_{\mathrm{RM}}$ are dermal $\mathrm{CD} 4^{+} \mathrm{T}$ cells that lack $\mathrm{CD} 103$ expression. However, we do find that $\mathrm{CD} 103^{+} \mathrm{T}$ cells, both $\mathrm{CD} 4^{+}$and $\mathrm{CD} 8^{+}$, are enriched in the epidermis. With respect to their functional capacities, $\mathrm{CD}_{103^{+}} \mathrm{T}_{\mathrm{RM}}$ had more potent effector functions but a poorer proliferative capacity. T cells isolated from the epidermis, which are enriched for $\mathrm{CD} 103^{+}$ $\mathrm{T}_{\mathrm{RM}}$, rapidly underwent apoptosis when removed from the skin microenvironment and had a poor proliferative capacity; these findings are very similar to the behavior of $\mathrm{CD} 103^{+} \mathrm{T}_{\mathrm{RM}}$ isolated from the brains of mice following infection with vesicular stomatitis virus (14).

Upregulation of CD103 by skin T cells in mouse models has been shown to occur after entry into the epidermis and to depend on TGF $\beta$ (15). A second study suggested IL-33 and TNFa may also contribute (16). We observed in human engrafted mice that $\mathrm{T}$ cells that had migrated into the epidermis had higher levels of CD103 than dermal T cells. Hypothesizing that contact with keratinocytes might participate in CD103 upregulation, we found that direct culture of stimulated blood T cells with keratinocyte monolayers enhanced CD103 expression in a manner that was TGF $\beta$ dependent but did not require adhesive interactions between T cells and keratinocytes. Moreover, exogenous TGF $\beta$ markedly enhanced CD103 induction in the presence or absence of direct keratinocyte contact. Although signaling from integrin and CD103-E-cadherin mediated adhesive interactions did not enhance CD103 upregulation, CD103-E-cadherin interactions did serve to tether T cells to keratinocyte monolayers. Taken together, these studies suggest that CD103 in human T cells is 
upregulated by TGF $\beta$ produced within the epidermal compartment. Although adhesive interactions with keratinocytes do not induce CD103 upregulation, CD103 likely participates in tethering $\mathrm{T}$ cells within the epidermal compartment.

In summary, we find that human skin is populated by a combination of $\mathrm{CD}_{103}{ }^{+}$and $\mathrm{CD}_{103}{ }^{-} \mathrm{T}_{\mathrm{RM}}$, with $\mathrm{CD} 4^{+} \mathrm{T}_{\mathrm{RM}}$ predominating. The preponderance of $\mathrm{CD}^{+} \mathrm{T}_{\mathrm{RM}}$ in human skin may reflect the diversity of antigen exposures encountered by individuals throughout their lifetimes. Most mouse models of $T_{R M}$ generation utilize viruses to induce $T_{R M}$ formation, including HSV and vaccinia infection, and these mice are kept in pathogen free barrier conditions to prevent other infections $(5,6)$. In contrast, our healthy adult human skin donors will have been exposed to a combination of viral, bacterial, fungal and possibly parasitic infections. It is worth noting that the antigen specificities of human skin $\mathrm{T}_{\mathrm{RM}}$ are a valuable immunologic record of what infectious pathogens and antigens an individual has been exposed to during his or her lifetime. Moreover, encoded within the cytokine and effector functions of these $\mathrm{T}$ cells is a history of how these individuals overcame each pathogen. There are currently no techniques that allow us to extrapolate antigen specificity from the sequences of the TCR receptor. However, once such techniques are developed, we will be able to investigate the immunologic history of an individual from the $\mathrm{T}$ cells remaining in their skin. Recent studies in mice showed that skin antigen exposures led individual naïve $T$ cells to differentiate into roughly equal numbers of skin resident $T_{R M}$ and recirculating $\mathrm{T}_{\mathrm{CM}}$, suggesting that immune reactions in skin generate $\mathrm{TCR}$ identical resident and recirculating $\mathrm{T}$ cell subsets (30).

We identified recirculating $\mathrm{T}$ cell subsets by studying the populations of $\mathrm{T}$ cells that were depleted from skin by alemtuzumab. Our prior work in patients with leukemic CTCL (LCTCL) treated with alemtuzumab found that human skin and the skin of CTCL patients contained a population of $\mathrm{T}$ cells that coexpressed both skin homing addressins (CLA/CC4) and central memory markers (CCR7/L-selectin) (2). In fact, in many patients with L-CTCL, malignant $\mathrm{T}$ cells had this phenotype (23). Alemtuzumab depleted these $\mathrm{T}$ cells from blood and purged them from the skin over time as well, confirming that they recirculate. $\mathrm{T}_{\mathrm{CM}}$, as first described, were thought to be a subset of $\mathrm{T}$ cells that recirculated between the blood and lymph nodes and lacked tissue tropism (20). However, skin tropic $\mathrm{T}_{\mathrm{CM}}$ exist in both the skin and blood in humans and would be expected to recirculate actively between the lymph nodes, blood and the skin. Indeed, a similar population of recirculating $\mathrm{T}$ cells was identified in the skin of Kaede mice (17). These T cells expressed co-expressed CCR7 and L-selectin at intermediate levels and recirculated between the blood, skin, and both skin draining and distant lymph nodes. These $\mathrm{T}$ cells had quantitatively lower levels of L-selectin expression than $\mathrm{T}$ cells from the circulation but expression was sufficient to allow these cells to recirculate through noncutaneous, distal lymph nodes (17). Because these T cells could access systemic lymph nodes, we believe they represent the analogous population in mice to cells we refer to as skin tropic $\mathrm{T}_{\mathrm{CM}}$.

We also found evidence for an additional population of $\mathrm{CCR} 7^{+} / \mathrm{L}$-selectin ${ }^{-}$recirculating $\mathrm{T}$ cells in human skin, which we refer to as migratory memory $\mathrm{T}$ cells $\left(\mathrm{T}_{\mathrm{MM}}\right)$. This population of recirculating $\mathrm{T}$ cells was poorly reproduced in our engrafted mouse model but was present in the blood and skin of healthy individuals and CTCL patients and was depleted by 
alemtuzumab therapy. In humans, $\mathrm{CLA}^{+} \mathrm{T}_{\mathrm{MM}}$ were the most prevalent subset of CLA ${ }^{+}$ memory $\mathrm{T}$ cells in the blood. $\mathrm{T}_{\mathrm{MM}}$ would presumably be excluded from lymph nodes draining noncutaneous tissues because they lacked L-selectin. However, they would access skin draining lymph nodes as they migrated out of the skin into the lymphatics and from there into skin draining lymph nodes. We found support for this concept in the clinical findings thatpatients with CTCL and $\mathrm{T}_{\mathrm{MM}}$ malignant $\mathrm{T}$ cells tended to have enlargement of only skin draining lymph nodes (termed dermatopathic nodes) but lacked diffuse lymph node involvement, a feature often observed in L-CTCL patients with $\mathrm{T}_{\mathrm{MM}}$ malignancies.

With respect to their functional capacities, $\mathrm{T}_{\mathrm{MM}}$ were intermediate between $\mathrm{T}_{\mathrm{CM}}$ and $\mathrm{T}_{\mathrm{RM}}$ in their production of inflammatory cytokines. Interestingly, we found that $\mathrm{Th} 2$ cytokine production was enriched in recirculating $\mathrm{T}$ cells $\left(\mathrm{T}_{\mathrm{MM}}\right.$ and $\left.\mathrm{T}_{\mathrm{CM}}\right)$ but that the production of Th1, Th2 Th17 and Th22 associated inflammatory cytokines was enriched in effector memory $\mathrm{T}$ cells $\left(\mathrm{T}_{\mathrm{EM}}\right)$. IL-2 was expressed at higher levels by recirculating $\mathrm{T}$ cells, consistent with a possible role for this cytokine in preventing apoptosis and maintaining cell viability during their turbulent and continual migration through the bloodstream and tissues.

Although the data we have are limited, our findings in human patients treated with alemtuzumab suggest $\mathrm{T}_{\mathrm{MM}}$ may recirculate more slowly through skin than $\mathrm{T}_{\mathrm{CM}}$. CTCL Patients with malignant $\mathrm{T}$ cells of a $\mathrm{T}_{\mathrm{MM}}$ phenotype developed ill-defined but discrete skin lesions, whereas L-CTCL patients with malignant $\mathrm{T}$ cells of a $\mathrm{T}_{\mathrm{CM}}$ phenotype had diffuse, often complete erythema of the skin (erythroderma). We hypothesize that the diffuse erythema caused by malignant $\mathrm{T}_{\mathrm{CM}}$ arises from the rapid migration of these cells in and out of skin and also within the skin itself. In contrast, $\mathrm{T}_{\mathrm{MM}}$ gave rise to ill-defined but discrete skin lesions, consistent with a slower migration of these $\mathrm{T}$ cells in and out of skin and within the skin itself. Moreover, in the one patient we were capable of studying, $\mathrm{T}_{\mathrm{MM}}$ were depleted more slowly from the skin than $\mathrm{T}_{\mathrm{CM}}$. However, an alternative explanation may be that $\mathrm{T}_{\mathrm{MM}}$ may be the subset of $\mathrm{T}$ cells that give rise to $\mathrm{T}_{\mathrm{RM}}$. In this case, the skin lesions we see developing these patients may represent $\mathrm{T}_{\mathrm{MM}}$ differentiating in situ into $\mathrm{T}_{\mathrm{RM}}$ at the sites. The continued development of new expanding skin lesions in these patients likely results from recirculating $\mathrm{T}_{\mathrm{MM}}$ entering new areas of skin from the blood stream and initiating new lesions. Whether the skin lesions generated by $\mathrm{T}_{\mathrm{RM}}$ represent newly generated $\mathrm{T}_{\mathrm{RM}}$ or simply a slower migration of $\mathrm{T}_{\mathrm{MM}}$ through skin remains to be determined. Lastly, it is not clear why $\mathrm{T}_{M M}$ are underrepresented in human engrafted mice. One possibility is that $\mathrm{T}_{\mathrm{MM}}$ may be a major source of $T_{R M}$ and are therefore depleted as $T_{R M}$ develop in the skin. $A$ second possibility is that the subset of human $\mathrm{T}$ cells may not survive well within the mouse microenvironment.

One caveat to our findings is that although we and other groups studying resident and recirculating $\mathrm{T}$ cell populations use designations such as $\mathrm{T}_{\mathrm{RM}}$ and $\mathrm{T}_{\mathrm{CM}}$ to describe subsets of T cells, markers such as CD69 and CCR7 that are used to define these putatively stable subsets can change with $\mathrm{T}$ cell activation. Additional work will be needed to identify exactly how stable these $\mathrm{T}$ cell subsets are and to identify additional, less variable surface markers to identify them. 
In summary, we present a thorough characterization of resident and recirculating memory $\mathrm{T}$ cells in human skin. We find that two discrete populations of $\mathrm{T}_{\mathrm{RM}}$ are stationed in human skin and two distinct populations of $\mathrm{T}$ cells recirculate through skin. Each of these subsets has distinct recirculation and functional capacities and each is likely to play a unique role in protection against known pathogens. Both $\mathrm{T}_{\mathrm{RM}}$ and recirculating $\mathrm{T}$ cells are known to contribute to human diseases. For example, psoriasis is a disorder of dysregulated $\mathrm{T}_{\mathrm{RM}}$ and L-CTCL represents a malignancy of recirculating $\mathrm{T}$ cells $(23,31-33)$. Recent findings in mice that $\mathrm{T}_{\mathrm{RM}}$ and recirculating $\mathrm{T}$ cells have very different patterns of gene expression highlight the fact that these cell types have a very distinct biology (15). Excepting the current study, the relative proportions of resident and recirculating $\mathrm{T}$ cells in human tissues remain uncharacterized. Moreover, the contribution of $\mathrm{T}_{\mathrm{RM}} \mathrm{vs}$. recirculating $\mathrm{T}$ cells to most human inflammatory and autoimmune diseases and the effects of anti-inflammatory therapies on these $\mathrm{T}$ cell subsets are unknown. A better understanding of these resident and recirculating $\mathrm{T}$ cell subsets is therefore critical to understand healthy immune responses and identify therapies that preferentially target pathogenic $\mathrm{T}$ cells in autoimmune and inflammatory diseases.

\section{Materials and Methods}

\section{Study design / Experimental design}

This is an experimental laboratory study performed on human tissue samples. All studies were performed in accordance with the Declaration of Helsinki. Blood from healthy individuals was obtained after leukapheresis, skin was obtained from healthy patients undergoing cosmetic surgery procedures. Blood and lesional skin from patients with CTCL were obtained from patients seen at the Dana-Farber/Brigham and Women's Cancer Center Cutaneous Lymphoma Program. L-CTCL and MF patients described in this manuscript met the WHO-EORTC criteria for L-CTCL/SS or MF (34). All tissues were collected with prior approval from the Partners and Dana Farber Institutional Review Board. Enumeration of $\mathrm{T}$ cell subsets in immunofluorescence studies was done in an investigator blinded fashion. Mechanistic studies on cells derived from blood and human tissues were performed using in vitro assays without blinding or randomization. Study components were not predefined.

\section{Human engrafted mouse model}

Human neonatal foreskins were grafted onto the backs of 6- to 8-week-old NOD/SCID/IL-2 receptor $\gamma$ chain $^{\text {null }}$ mice (Jackson Laboratories). One week later $5 \times 10^{6}$ allogeneic PBMC were injected i.v. after isolation from healthy donors by ficoll centrifugation. Antibody injections commenced 2-4 weeks after PBMC engraftment. Alemtuzumab $(2.5 \mu \mathrm{g})$ or isotype control (human IgG1, Biolegend) was injected i.p. 3 times/week for 3 weeks. AntiCD3-diphtheria toxin (A-dmDT(390)-bisFv(UCHT1), $0.625 \mu \mathrm{g}$ ) or isotype control (human IgG1) was injected i.v. once/day for 4 days. At the conclusion of the experiment, blood and skin grafts were harvested for analysis by flow cytometry, immunofluorescence and/or hematoxylin/eosin staining. 


\section{Skin and blood samples}

The protocols of this study were performed in accordance with the Declaration of Helsinki, and were approved by the Institutional Review Board of the Partners Human Research Committee (Partners Research Management). Skin from healthy patients was obtained from patients undergoing cosmetic surgery procedures and blood from healthy individuals was obtained as discarded tissue following leukopheresis. Neonatal foreskins were obtained from infants undergoing circumcision at the Brigham and Women's Hospital. Blood and lesional skin from patients with CTCL were obtained from patients seen at the Dana-Farber/Brigham and Women's Cancer Center Cutaneous Lymphoma Program. L-CTCL and MF patients described in this manuscript met the WHO-EORTC criteria for CTCL. PBMC were isolated by ficoll centrifugation.

\section{T cell isolation from skin}

Full thickness human skin samples, fresh or after engraftment on mice, were extensively minced and then incubated for 2 hours at $37^{\circ} \mathrm{C}$ in RPMI 1640 containing $0.2 \%$ collagenase type I (Life Technologies) and deoxyribonuclease I (30 Kunitz units/ml, Sigma Aldrich). Thereafter, cells were collected by filtering the collagenase-treated tissue through a 40- $\mu \mathrm{m}$ cell strainer. For some experiments, epidermis and dermis were separated by overnight incubation in dispase II (1.4 IU/ml, Roche Diagnostics) at $4^{\circ} \mathrm{C}$ followed by mechanical separation. Epidermis was then minced and incubated with dispase for an additional $30 \mathrm{~min}$ at $37^{\circ} \mathrm{C}$ with agitation followed by filtration through a $40-\mu \mathrm{m}$ cell strainer. Dermis was minced and treated with collagenase as per full thickness skin protocol. Cells from whole skin, dermis or epidermis were incubated at $37^{\circ} \mathrm{C}$ for 2 days in Iscove's DMEM supplemented with $20 \%$ fetal bovine serum, penicillin/streptomycin, glutamine and 2mercaptoethanol prior to flow cytometry analysis. When indicated (Fig. S2), the pan-caspase inhibitor Z-VAD-FMK (R\&D Systems) was included at low $(10 \mu \mathrm{M})$ or high $(100 \mu \mathrm{M})$ concentrations to inhibit apoptosis.

\section{Flow cytometry}

Analysis of $\mathrm{T}$ cells was performed using directly conjugated monoclonal antibodies obtained from BD Biosciences, eBioscience, Biolegend, Beckman Coulter or R\&D Systems.. Isotypematched negative control antibodies were used to set the gates for positive staining. For analysis of cytokine production, $\mathrm{T}$ cells were stimulated with either control medium or 50 $\mathrm{ng} / \mathrm{ml}$ PMA (Sigma Aldrich) and $750 \mathrm{ng} / \mathrm{ml}$ ionomycin (Life Technologies) plus $10 \mu \mathrm{g} / \mathrm{ml}$ Brefeldin A (BD Biosciences) for four hours. Cells were surface stained, fixed, permeabilized, stained with anti-cytokine antibodies, and examined by flow cytometry. For analysis of proliferation, cells were surface stained, fixed, permeabilized, stained with antiKi-67 antibody, and examined by flow cytometry. Analysis of flow cytometry samples was performed on Becton Dickinson FACSCanto instruments and data were analyzed using FACSDiva software (V5.1).

\section{Cryosection immunostaining}

Human skin grafts were embedded in OCT, frozen, and stored at $-80^{\circ} \mathrm{C}$ until use. $5-\mu \mathrm{m}$ cryosections were cut, air dried, fixed for $5 \mathrm{~min}$ in acetone, rehydrated in PBS, and blocked 
with $20 \mu \mathrm{g} / \mathrm{ml}$ of human IgG (Jackson ImmunoResearch Laboratories) for $15 \mathrm{~min}$ at room temperature. Sections were incubated with primary antibody for $30 \mathrm{~min}$, and then rinsed three times in PBS/1\% BSA for 5 min. If necessary, secondary antibody was added for 30 min, followed by three rinses. Sections were mounted using Prolong Gold Antifade with DAPI (Life Technologies) and examined immediately by immunofluorescence microscopy. Antibodies were obtained from the following: Biolegend (CD3, CD69), LifeSpan BioSciences (CD103), Abcam (cytokeratin 15) and Jackson Immunoresearch (secondary antibodies). Sections were photographed using a microscope (Eclipse 6600; Nikon) equipped with a $40 \times / 0.75$ objective lens (Plan Fluor; Nikon). Images were captured with a camera (SPOT RT model 2.3.1; Diagnostic Instruments) and were acquired with SPOT 4.0.9 software (Diagnostic Instruments).

\section{Proliferation and cytokine analysis of cells stimulated within explants}

Ten mm punch biopsies of healthy adult skin were injected with $100 \mu \mathrm{l}$ of PBS (control), aCD3/a-CD28 antibody mixture (0.5 $\mu \mathrm{g} / \mathrm{ml}$ each), or heat-killed Staphylococcus aureus $\left(10^{6} / \mathrm{ml}\right.$, ATCC) or Candida albicans $\left(5 \times 10^{3} / \mathrm{ml}\right.$, ATCC). Biopsies were floated in $0.4 \mu \mathrm{m}$ pore size Transwell inserts in X-VIVO 15 medium (Lonza). After 2 weeks cell that had migrated out of the biopsies were collected, rested overnight in X-VIVO 15 medium, and analyzed for cytokine production and proliferation by flow cytometry as described above. Only cells that had migrated out of the explants were analyzed.

\section{In vitro studies of CD103 regulation}

To obtain keratinocytes, healthy human skin was separated into epidermis and dermis by incubating with $1.4 \mathrm{IU} / \mathrm{ml}$ of dispase II (Roche) in RPMI (Life Technologies) at $4^{\circ} \mathrm{C}$ for 12 hrs. Epidermis was peeled away from the dermis, minced and further digested with 1.4IU/ml dispase at $37^{\circ} \mathrm{C}$ for $30 \mathrm{~min}$, then filtered in a cell strainer. Keratinocytes were cultured to confluence in 24-well flat-bottomed plates using keratinocyte-FCM media (Life Technologies). To obtain fibroblasts, the dermis was minced, digested with $0.2 \%$ collagenase/DNase (Sigma Aldrich) at $37^{\circ} \mathrm{C}$ for 2 hours, then filtered in a cell strainer. Fibroblasts were cultured to confluence in RPMI supplemented with $15 \%$ FCS and $10 \mathrm{ng} / \mathrm{ml}$ EGF. $\mathrm{CD}^{+}{ }^{+} \mathrm{CD} 4^{+}$and $\mathrm{CD}^{+} \mathrm{CD} 8^{+} \mathrm{T}$ cells were isolated using magnetic separation (negative isolation kits, Miltenyi Biotec) from healthy human PBMC. CD103 was expressed by a mean 3\% of the isolated CD8 T cells but otherwise surface expression of CD69 and CD103 was $<1 \%$ in these $\mathrm{T}$ cell fractions. $1 \times 10^{5} \mathrm{~T}$ cells were stimulated with $\mathrm{aCD} 3 / \mathrm{CD} 2 / \mathrm{CD} 28 \mathrm{~T}$ cell activation beads (Miltenyi Biotec) with 1:2 ratio for $24 \mathrm{hrs}$ (day 0) and then added to keratinocytes or fibroblasts monolayers (day 1) in Iscove's Modified Dulbecco's Media (Corning) supplemented with 10\% FCS and L-glutamine. For indirect cultures, transwells with $0.4 \mu \mathrm{m}$ polyester membrane (Corning) were used to separate $\mathrm{T}$ cells from fibroblasts and keratinocyte monolayers. Neutralizing abs for TGF $\beta$ (R \& D), E-Cadherin (Millipore), LFA-1 (Biolegend) and Integrin $\beta 1(\mathrm{R} \& \mathrm{D})$ and recombinant human TGF $\beta(\mathrm{R} \& \mathrm{D})$ were added to co-cultures system with final concentration of $10 \mu \mathrm{g} / \mathrm{ml}$. T cells were collected by washing on day 6 after starting co-culture. Adherent T cells were counted by microscopy and collected by incubating the wells with trypsin/EDTA (Gemini Bio-Products) for $5 \mathrm{~min}$ at $37^{\circ} \mathrm{C}$. 


\section{CyTOF mass cytometry analysis of peripheral blood T cells}

T cells were isolated from healthy donor PBMC by depletion of non-T cells using the Pan T isolation kit and AutoMacs separator (Miltenyi Biotec). T cells were pre-treated with TAPI-2 (100 $\mu \mathrm{M}$, Sigma Aldrich) for $1 \mathrm{hr}$ prior to stimulation and during the $4 \mathrm{hr}$ of stimulation with PMA/ionomycin plus brefeldin A to prevent stimulation-induced cleavage of L-selectin (35). Following stimulation, T cells were stained with surface marker metalconjugated antibodies (MCA, Fluidigm, Inc.) at concentrations found to be effective in prior antibody tests. After surface staining, cells were fixed, permeabilized and stained with MCA intracellular antibodies for $30 \mathrm{~min}$ at room temperature. The cells were then labeled overnight at $4^{\circ} \mathrm{C}$ with $125 \mathrm{nM}$ DNA intercalator (Fluidigm, Inc). Finally, the cells were diluted to the appropriate concentration in distilled water containing $10 \% \mathrm{EQ}^{\mathrm{TM}}$ Four Element Calibration Beads (Fluidigm, Inc) to achieve an acquisition rate $<500$ events/s on the CyTOF2 instrument using the recommended default settings for the CyTOF2 (Fluidigm, Inc). CyTOF data were normalized to the beads through the CyTOF2 software after acquisition without bead removal and using default settings (Fluidigm, Inc). After built-in cell-identifying software created a FCS file, CyTOF data were analyzed in a manner similar to standard flow cytometry analysis by FCS express software 4.0 (De Novo Software) using DNA content and normalization beads to identify single-cell events.

\section{Statistical analyses}

Primary methods of data analysis included descriptive statistics (means, medians and s.d.). Differences between two sample groups were detected using the one tailed WilcoxonMann-Whitney test, $a=0.05$. For comparisons of multiple groups, a Kruskal-Wallis oneway analysis of variance with a Bonferroni-Dunn's post test for multiple means test was used, $a=0.05$.

\section{Supplementary Material}

Refer to Web version on PubMed Central for supplementary material.

\section{Acknowledgments}

The authors would like to thank the patients who made this work possible, both for entrusting us with their clinical care and for donating skin and blood samples. A-dmDT(390)-bisFv(UCHT1) was generously and kindly provided by Drs. Jung-Hee Woo (Dept. Internal Medicine Scott and White Memorial Hospital College of medicine, The Texas A\&M University System Health Science Center), David Neville (Section on Biophysical Chemistry, Laboratory of Molecular Biology, National Institute of Mental Health) and Arthur E. Frankel (Department of Medicine, Simmons Comprehensive Cancer Center, UT Southwestern Medical Center). Dr. Thomas Cochran of the Boston Center for Plastic Surgery and Drs. Bohdan Pomahac, Simon Talbot and Elof Eriksson of Brigham and Women's Hospital generously provided adult human skin samples. We thank Dr. George Murphy, Chief of the Dermatopathology Division, Department of Pathology at Brigham and Women's Hospital for his assistance in photographing histologic sections.

Funding: This work was supported by a generous charitable contribution from Edward P. Lawrence, Esq., R01 AR063962 NIH/NIAMS (to R.A.C.), R01 AR056720 NIH/NIAMS (to R.A.C.), a Damon Runyon Clinical Investigator Award (to R.A.C.), the SPORE in Skin Cancer P50 CA9368305 NIH/NCI (to T.S.K.) and R01 AI097128 NIAID (to T.S.K. and R.A.C.).R.W. salary support was provided by a Special Scholar Grant from the Leukemia and Lymphoma Society. Salary support for C.S. was provided by the Swiss National Science Foundation and the Fondation Rene Touraine. 


\section{References}

1. Carbone FR, Mackay LK, Heath WR, Gebhardt T. Distinct resident and recirculating memory T cell subsets in non-lymphoid tissues. Current opinion in immunology. Jun.2013 25:329. [PubMed: 23746791]

2. Clark RA, et al. Skin effector memory T cells do not recirculate and provide immune protection in alemtuzumab-treated CTCL patients. Science Translational Medicine. Jan 18.2012 4:117ra7.

3. Clark RA. Resident memory T cells in human health and disease. Science Translational Medicine. 2015 In press.

4. Siders WM, et al. Involvement of neutrophils and natural killer cells in the anti-tumor activity of alemtuzumab in xenograft tumor models. Leukemia \& lymphoma. Jul.2010 51:1293. [PubMed: 20377308]

5. Jiang X, et al. Skin infection generates non-migratory memory CD8+ TRM cells providing global skin immunity. Nature. Mar 8.2012 483:227. [PubMed: 22388819]

6. Gebhardt T, et al. Memory T cells in nonlymphoid tissue that provide enhanced local immunity during infection with herpes simplex virus. Nature immunology. 2009; 10:524. [PubMed: 19305395]

7. Clark RA, et al. The vast majority of CLA+ T cells are resident in normal skin. The Journal of Immunology. Apr 1.2006 176:4431. [PubMed: 16547281]

8. Lessin SR, Vowels BR, Rook AH. Th2 cytokine profile in cutaneous T-cell lymphoma. The Journal of investigative dermatology. Dec.1995 105:855. [PubMed: 7490483]

9. Guenova E, et al. TH2 cytokines from malignant cells suppress TH1 responses and enforce a global TH2 bias in leukemic cutaneous T-cell lymphoma. Clinical Cancer Research. Jul 15.2013 19:3755. [PubMed: 23785046]

10. Vowels BR, Cassin M, Vonderheid EC, Rook AH. Aberrant cytokine production by Sezary syndrome patients: cytokine secretion pattern resembles murine Th2 cells. The Journal of investigative dermatology. Jul.1992 99:90. [PubMed: 1607682]

11. Dummer R, et al. Sezary syndrome T-cell clones display T-helper 2 cytokines and express the accessory factor-1 (interferon-gamma receptor beta-chain). Blood. Aug 15.1996 88:1383. [PubMed: 8695857]

12. Zhu J, et al. Virus-specific CD8+ T cells accumulate near sensory nerve endings in genital skin during subclinical HSV-2 reactivation. The Journal of experimental medicine. Mar 19.2007 204:595. [PubMed: 17325200]

13. Zhu J, et al. Immune surveillance by CD8alphaalpha+ skin-resident $\mathrm{T}$ cells in human herpes virus infection. Nature. May 23.2013 497:494. [PubMed: 23657257]

14. Wakim LM, et al. The molecular signature of tissue resident memory CD8 T cells isolated from the brain. J Immunol. Oct 1.2012 189:3462. [PubMed: 22922816]

15. Mackay LK, et al. The developmental pathway for CD103(+)CD8+ tissue-resident memory T cells of skin. Nature immunology. Dec.2013 14:1294. [PubMed: 24162776]

16. Skon CN, et al. Transcriptional downregulation of S1pr1 is required for the establishment of resident memory CD8+ T cells. Nature immunology. Dec.2013 14:1285. [PubMed: 24162775]

17. Bromley SK, Yan S, Tomura M, Kanagawa O, Luster AD. Recirculating memory T cells are a unique subset of CD4+ T cells with a distinct phenotype and migratory pattern. J Immunol. Feb 1.2013 190:970. [PubMed: 23255361]

18. Bromley SK, Thomas SY, Luster AD. Chemokine receptor CCR7 guides T cell exit from peripheral tissues and entry into afferent lymphatics. Nature immunology. Sep.2005 6:895. [PubMed: 16116469]

19. Debes GF, et al. Chemokine receptor CCR7 required for T lymphocyte exit from peripheral tissues. Nature immunology. Sep.2005 6:889. [PubMed: 16116468]

20. Sallusto F, Lenig D, Forster R, Lipp M, Lanzavecchia A. Two subsets of memory T lymphocytes with distinct homing potentials and effector functions. Nature. Oct 14.1999 401:708. [PubMed: 10537110] 
21. Butcher EC, Williams M, Youngman K, Rott L, Briskin M. Lymphocyte trafficking and regional immunity. Adv Immunol. 1999; 72:209. [PubMed: 10361577]

22. Sallusto F, Geginat J, Lanzavecchia A. Central Memory and Effector Memory T Cell Subsets: Function, Generation, and Maintenance. Annual review of immunology. 2004; 22:745.

23. Campbell JJ, Clark RA, Watanabe R, Kupper TS. Sezary syndrome and mycosis fungoides arise from distinct T-cell subsets: a biologic rationale for their distinct clinical behaviors. Blood. Aug 5.2010 116:767. [PubMed: 20484084]

24. Watanabe R, Teague JE, Fisher DC, Kupper TS, Clark RA. Alemtuzumab Therapy for Leukemic Cutaneous T-Cell Lymphoma: Diffuse Erythema as a Positive Predictor of Complete Remission. JAMA dermatology. Apr 23.2014

25. Benichou G, et al. Immune recognition and rejection of allogeneic skin grafts. Immunotherapy. Jun.2011 3:757. [PubMed: 21668313]

26. Frankel AE, et al. Anti-CD3 recombinant diphtheria immunotoxin therapy of cutaneous T cell lymphoma. Current drug targets. Feb.2009 10:104. [PubMed: 19199905]

27. Sathaliyawala T, et al. Distribution and compartmentalization of human circulating and tissueresident memory T cell subsets. Immunity. Jan 24.2013 38:187. [PubMed: 23260195]

28. Shiow LR, et al. CD69 acts downstream of interferon-alpha/beta to inhibit S1P1 and lymphocyte egress from lymphoid organs. Nature. Mar 23.2006 440:540. [PubMed: 16525420]

29. Gebhardt T, et al. Different patterns of peripheral migration by memory CD4+ and CD8+ T cells. Nature. Sep 8.2011 477:216. [PubMed: 21841802]

30. Gaide O, Emerson RO, Jiang X, Nizza S, Desmarais C, Robins H, Clark RA, Kupper TS. Naive T cells give rise equally to TCR-identical TRM and TCM after skin antigen exposure, which exist in separate anatomic compartments and have different roles in long term memory. Nature medicine. 2014 In press.

31. Suarez-Farinas M, Fuentes-Duculan J, Lowes MA, Krueger JG. Resolved psoriasis lesions retain expression of a subset of disease-related genes. Journal of Investigative Dermatology. Feb.2011 131:391. [PubMed: 20861854]

32. Cheuk S, et al. Epidermal Th22 and Tc17 cells form a localized disease memory in clinically healed psoriasis. J Immunol. Apr 1.2014 192:3111. [PubMed: 24610014]

33. Boyman O, et al. Spontaneous development of psoriasis in a new animal model shows an essential role for resident $\mathrm{T}$ cells and tumor necrosis factor-alpha. The Journal of experimental medicine. Mar 1.2004 199:731. [PubMed: 14981113]

34. Willemze R, et al. WHO-EORTC classification for cutaneous lymphomas 10.1182/ blood-2004-09-3502. Blood. May 15.2005 105:3768. [PubMed: 15692063]

35. Jabbari A, Harty JT. Simultaneous assessment of antigen-stimulated cytokine production and memory subset composition of memory CD8 T cells. Journal of immunological methods. Jun 30.2006 313:161. [PubMed: 16762359] 


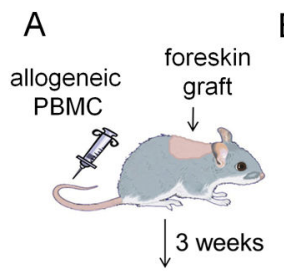

dermatitis

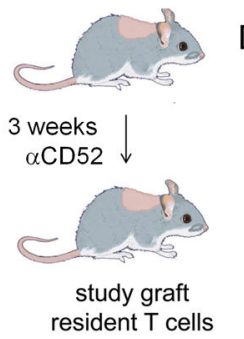

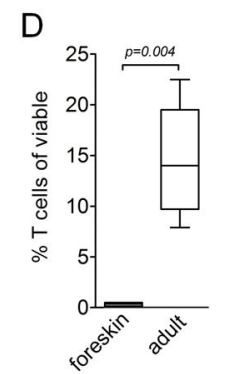

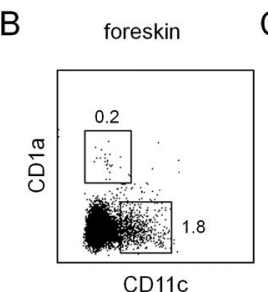

CD11c

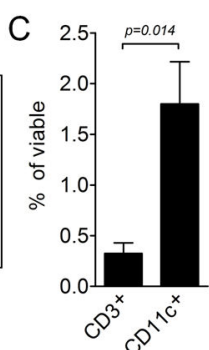

E

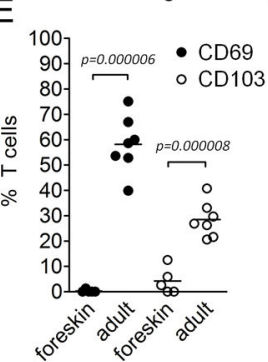

$\mathrm{H}$
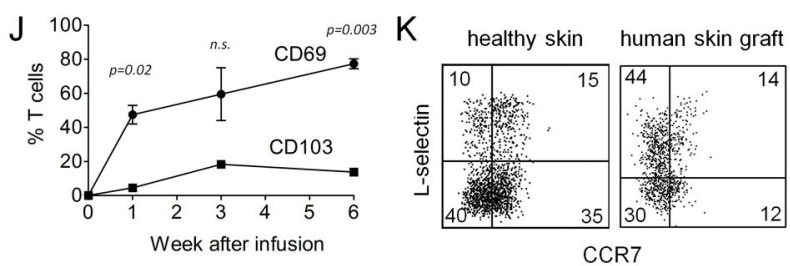

CCR7
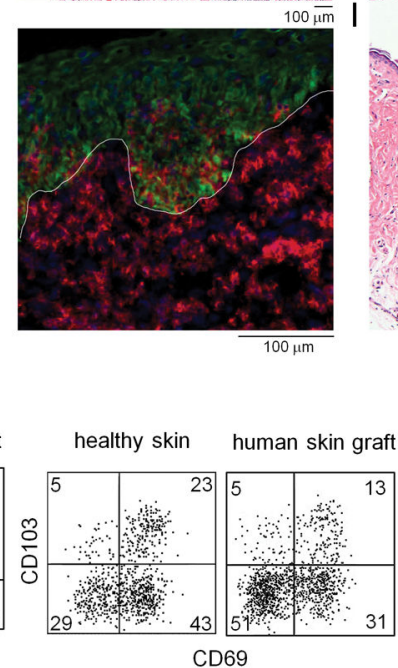

F
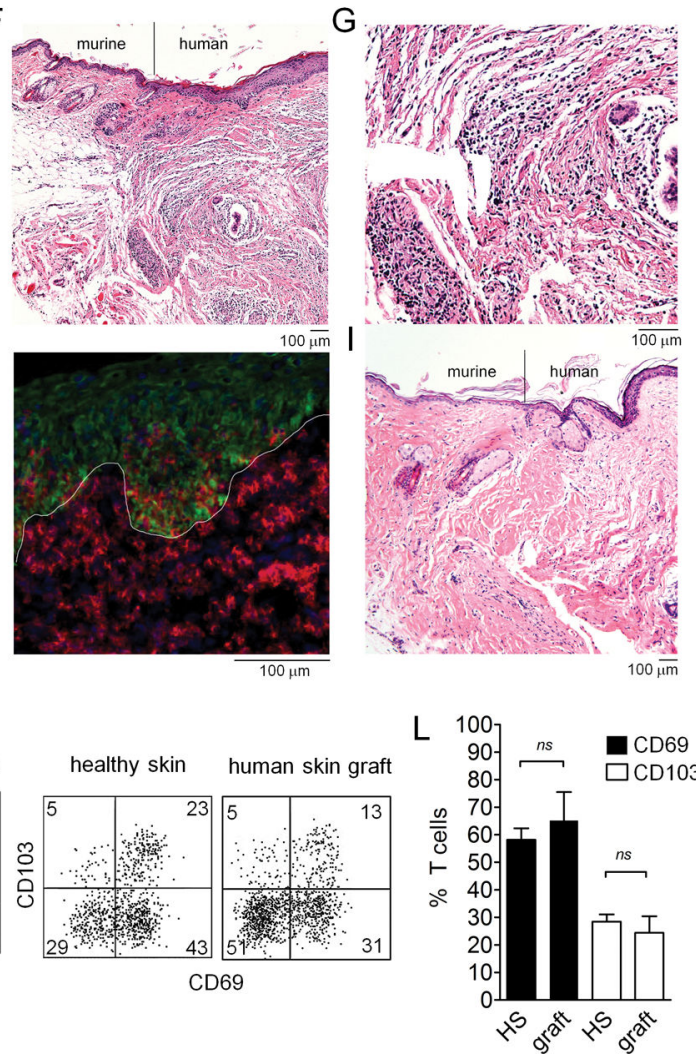

Figure 1. Skin $\mathbf{T}$ cells in a human engrafted mouse model recapitulate $\mathbf{T}$ cell populations in adult human skin

(A) A human engrafted mouse model was used to discriminate resident from recirculating $\mathrm{T}$ cells in skin. NSG mice were grafted with human foreskin and injected i.v. with allogeneic human PBMC, and alemtuzumab (aCD52) was used to deplete recirculating human T cells from grafted human skin. (B-E) human foreskins contained resident APC but few T cells.

(B) Flow cytometry staining of collagenase digested foreskin demonstrated both CD11 $\mathrm{c}^{+}$ $\mathrm{DC}$ and $\mathrm{CD} 1 \mathrm{a}^{+} \mathrm{LC}$ were present in foreskin. (C) Approximately four-fold more DC than T cells were present in foreskin, as assayed by the \% viable cells of each cell type in collagenase digested foreskin. (D) $\mathrm{T}$ cells were 45 -fold more frequent in healthy adult human skin than in foreskins; the percentage of $\mathrm{CD}^{+} \mathrm{T}$ cells in collagenase digested foreskin versus adult skin is shown. (E) The few T cells present in human foreskin lacked markers characteristic of $\mathrm{T}_{\mathrm{RM}}$. The percent of $\mathrm{T}$ cells expressing each marker in collagenase treated foreskin and adult skin are shown. The mean and SEM of four foreskins (C-E) and seven adult skin donors (D,E) are shown (test: T-test). (F-H) allogeneic PBMC injected i.v. into grafted mice migrated specifically into the human skin graft and induced an inflammatory dermatitis. Images are representative of eight PBMC injected and eight saline injected mice. (F) H\&E stained section demonstrating the junction between mouse and human skin in grafted mice. (G) H\&E stain, 20X view of inflammatory dermatitis. (H) A cryosections of human grafted skin immunostained for CD3 (red) and keratin (green) are shown. $\mathrm{T}$ cells were evident in both the dermis and the epidermis. The dermoepidermal junction is indicated by a white line. (I) in the absence of infused allogeneic PBMC, no 
inflammatory infiltrate was observed and few or no T cells were visualized in skin. (J) CD69 up-regulation preceded CD103 up-regulation in T cells migrating into human skin grafts. Human skin grafts were harvested at the indicated time points, collagenase digested, and T cells were analyzed for CD69 and CD103 expression by flow cytometry. The mean and SEM of two grafted mice per time point are shown (test: T-test). (K,L) T cell populations in grafted skin recapitulate those observed in adult human skin. T cell expression of $\mathrm{T}_{\mathrm{CM}}$ (CCR7/L-selectin) and $\mathrm{T}_{\mathrm{RM}}(\mathrm{CD} 69 / \mathrm{CD} 103)$ markers as assayed by flow cytometry are shown. $\mathrm{T}$ cells were isolated by collagenase digestion from healthy adult human skin or from skin grafts on PBMC infused mice. Representative histograms (K) and mean and SEM of expression of CD69 and CD103 are shown. The mean and SEM of three grafts and seven healthy skin donors are shown (test: T-test). 
A

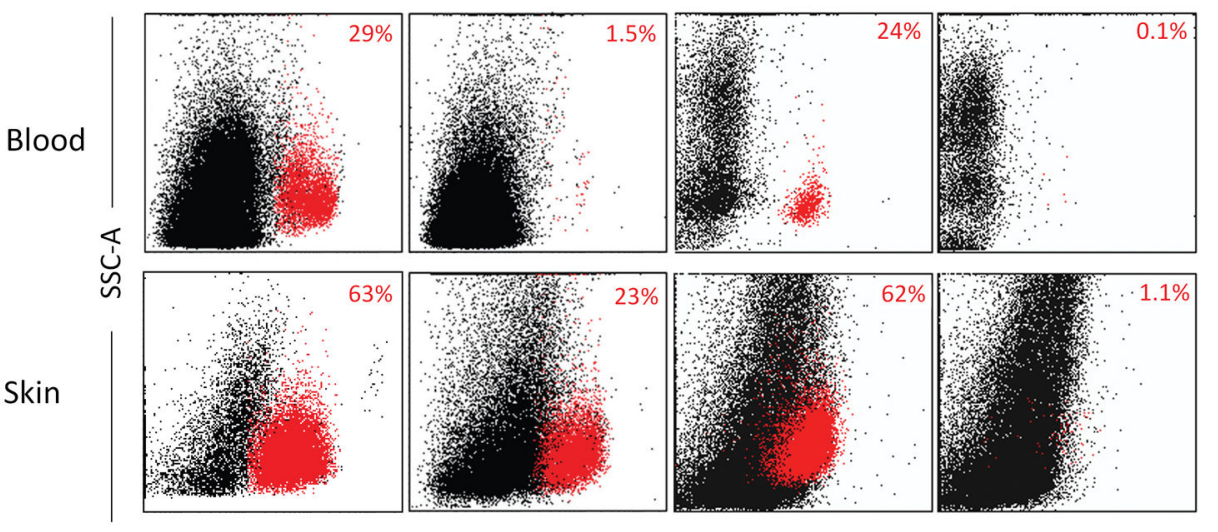

Human CD3
B

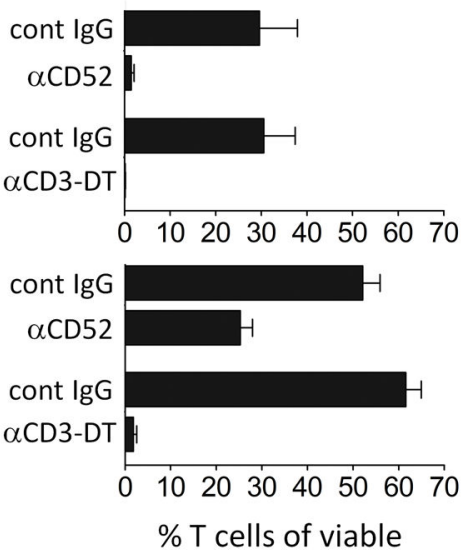

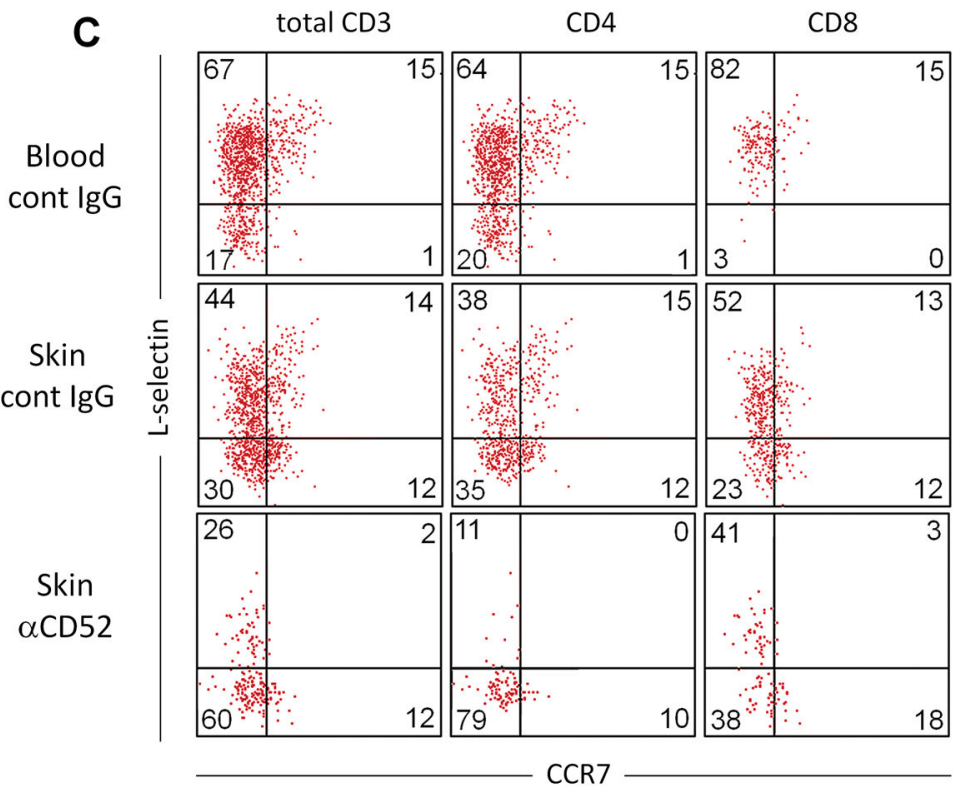

D

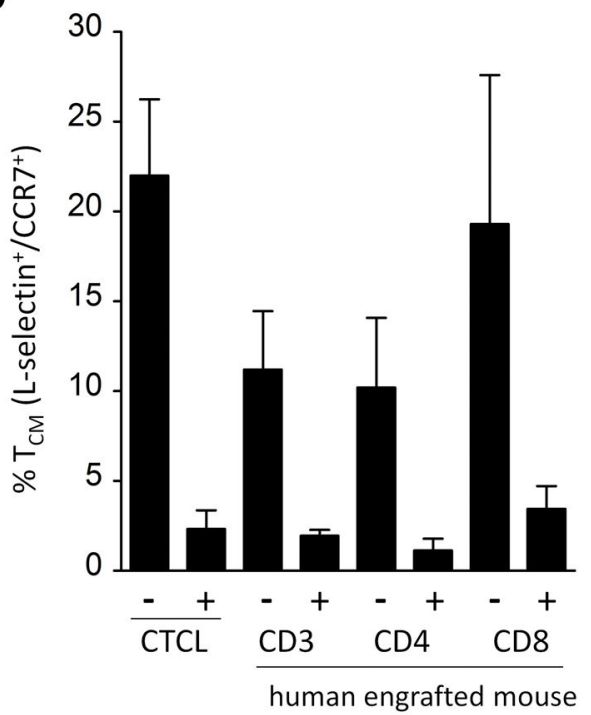

Figure 2. Alemtuzumab depletes recicrulating $\mathbf{T}_{\mathrm{CM}}$ from skin in human engrafted mice but spares a population of skin $T$ cells

(A, B) Shown are human T cells isolated from peripheral blood (Blood) and collagenase digested foreskin grafts (Skin) stained for CD3 and analyzed by flow cytometry. Samples were obtained from human engrafted mice after treatment with either control $\mathrm{IgG}$, alemtuzumab (aCD52) or with the anti-CD3-diphtheria immunotoxin A-dmDT(390)bisFv(UCHT1) (aCD3-DT). Representative dot plots (A) and aggregate data (B) are shown from four control IgG (alemtuzumab control) injected mice, six alemtuzumab injected mice, two control IgG (aCD3-DT control) injected mice and two aCD3-DT treated mice. (C) $\mathrm{CCR}^{+} / \mathrm{L}$-selectin ${ }^{+} \mathrm{T}_{\mathrm{CM}}$ were present in the blood and skin of human engrafted mice and were depleted in the skin by alemtuzumab. T cells isolated from the blood and skin of control IgG treated mice and the skin of alemtuzumab treated (aCD52) human engrafted mice are shown. (D) Aggregate data showing depletion of CCR7 $7^{+} / \mathrm{L}$-selectin ${ }^{+} \mathrm{T}_{\mathrm{CM}}$ in skin grafts of human engrafted mice treated with control $\operatorname{IgG}(-)$ or alemtuzumab (+). Depletion of $\mathrm{T}_{\mathrm{CM}}$ among the $\mathrm{CD}^{+}, \mathrm{CD}^{+}$and $\mathrm{CD}^{+} \mathrm{T}$ cell populations are shown. The mean and 
SEM of three grafted mice per group are shown. For comparison, the numbers of $\mathrm{CCR} 7^{+} / \mathrm{L}-$ selectin ${ }^{+} \mathrm{T}_{\mathrm{CM}}$ in the skin of five human CTCL patients (CTCL) before (-) and after (+) alemtuzumab therapy are shown. 

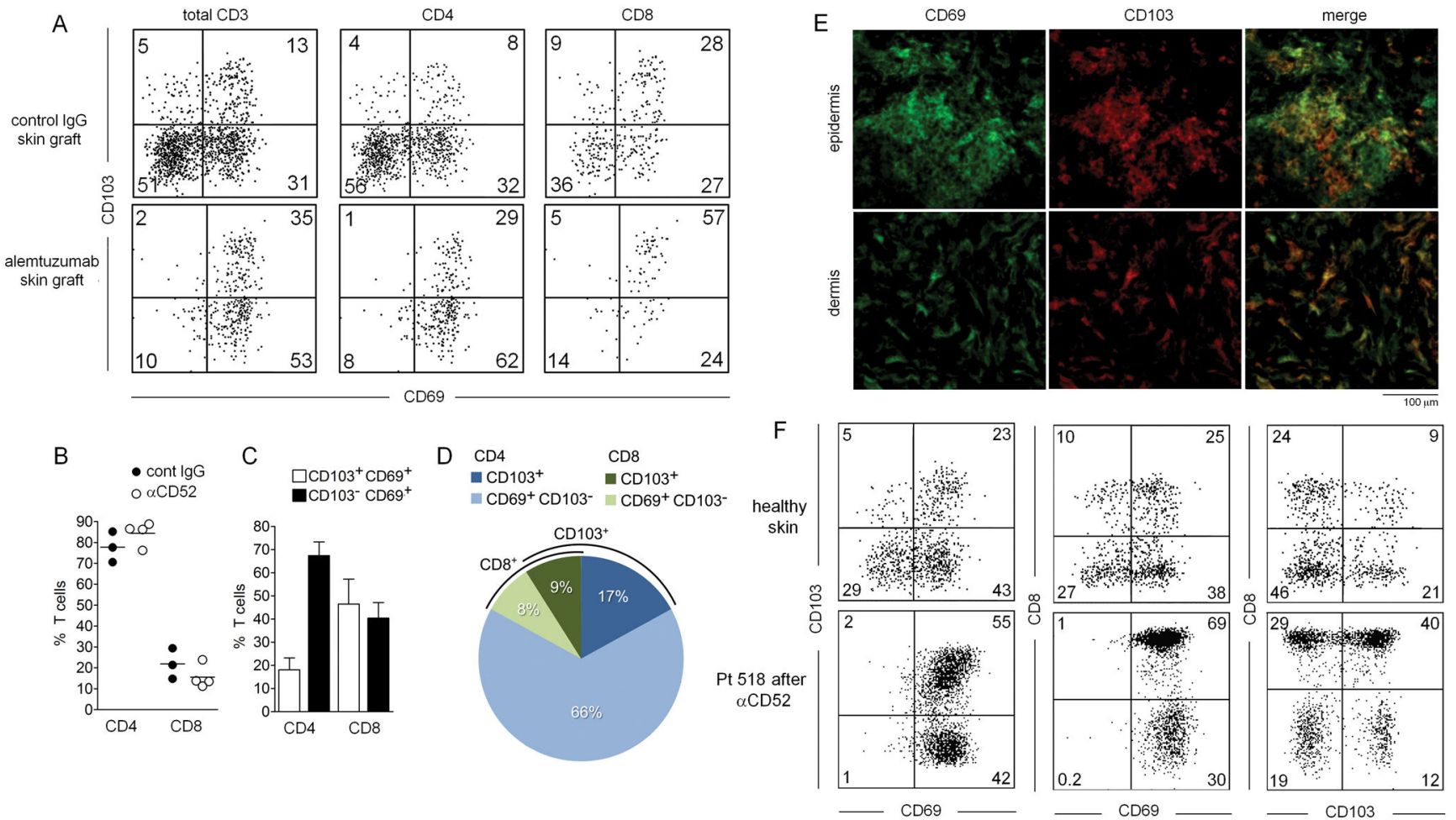

Figure 3. Distinct populations of non-recirculating $\mathrm{CD} 103^{+}$and $\mathrm{CD}{ }^{-} 3^{-} \mathrm{T}_{\mathrm{RM}}$ exist in human skin engrafted mice and in human skin

(A) $\mathrm{T}_{\mathrm{RM}}$ cells remaining in the human skin grafts of mice after alemtuzumab treatment expressed CD69 and a subset coexpressed CD103. (B) The relative percentages of CD4 ${ }^{+}$ and $\mathrm{CD} 8^{+} \mathrm{T}$ cells in human skin grafts did not change appreciably after alemtuzumab treatment. Shown are the percentage of total $\mathrm{CD} 4^{+}$and $\mathrm{CD} 8^{+} \mathrm{T}$ cells in three control $\mathrm{IgG}$ (cont $\mathrm{IgG}$ ) and four alemtuzumab (aCD52) treated mice (test: T-test). (C) Most CD4 ${ }^{+} \mathrm{T}_{\mathrm{RM}}$ cells were $\mathrm{CD} 69^{+} / \mathrm{CD} 103^{-}$whereas the majority of $\mathrm{CD} 8^{+} \mathrm{T}$ cells expressed both $\mathrm{CD} 69$ and CD103. (D) $\mathrm{CD}^{+} / \mathrm{CD} 69^{+} / \mathrm{CD} 103^{-} \mathrm{T}$ cells were the most frequent $\mathrm{T}_{\mathrm{RM}}$ population in alemtuzumab treated human engrafted mice. The relative percentages of the indicated $T_{R M}$ subsets are shown. (E) $\mathrm{CD}_{103}{ }^{+}$and $\mathrm{CD}_{103}{ }^{-} \mathrm{T}_{\mathrm{RM}}$ were found in both the epidermis and the dermis of human engrafted mice after alemtuzumab treatment. (F) Confirmatory studies in human patients demonstrated that $\mathrm{CD} 103^{+}$and $\mathrm{CD} 103^{-} \mathrm{T}_{\mathrm{RM}}$ also exist in human skin following treatment with alemtuzumab. $\mathrm{CD}^{+} \mathrm{T}$ cells isolated from healthy skin (top row of histograms) and the skin of a CTCL patient after alemtuzumab treatment (bottom row of histograms) are shown. Similar to the findings in human engrafted mice, CD69 was expressed by virtually all $\mathrm{T}_{\mathrm{RM}}, \mathrm{CD} 4^{+}$and $\mathrm{CD} 8^{+} \mathrm{T}_{\mathrm{RM}}$ of both subsets were observed, and $\mathrm{CD}^{+} \mathrm{T}$ cells were more frequently $\mathrm{CD} 103^{-}$whereas $\mathrm{CD} 8^{+} \mathrm{T}_{\mathrm{RM}}$ were more frequently $\mathrm{CD}_{103}{ }^{+}$. Results are representative of data from three treated patients. 


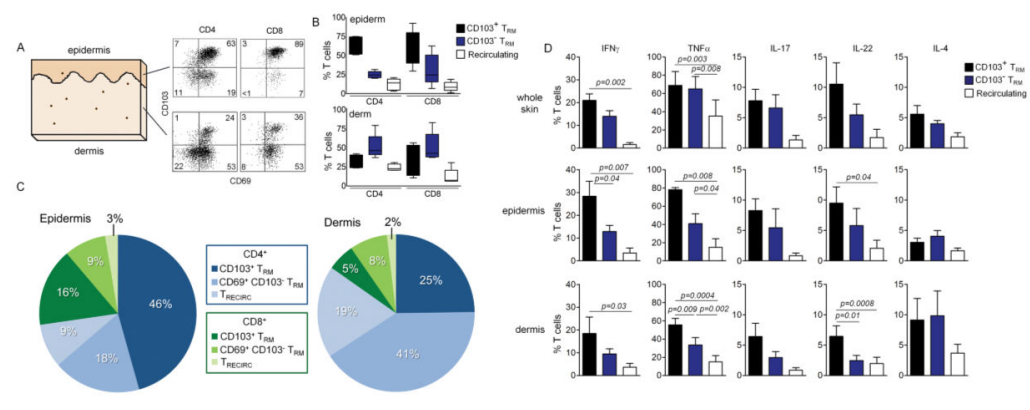

Figure 4. Two phenotypically and functionally distinct populations of $\mathbf{T}_{\mathbf{R M}}$ exist in healthy adult human skin

$(\mathbf{A}, \mathbf{B}, \mathbf{C})$ Adult human skin was enzymatically separated into epidermis and dermis, $\mathrm{T}$ cells were then isolated and analyzed by flow cytometry for the expression of $\mathrm{T}_{\mathrm{RM}}$ markers CD69 and CD103. Representative histograms (A) and aggregate data from 5 donors $(\mathbf{B}, \mathbf{C})$ are shown. The percentages of $\mathrm{CD}^{+} 9^{+} / \mathrm{CD} 103^{+}\left(\mathrm{CD} 103^{+} \mathrm{T}_{\mathrm{RM}}\right), \mathrm{CD} 9^{+} / \mathrm{CD} 103^{-}\left(\mathrm{CD} 103^{-} \mathrm{T}_{\mathrm{RM}}\right)$ and $\mathrm{CD}^{-} 9^{-} / \mathrm{CD} 103^{-}$(Recirculating) $\mathrm{T}$ cells as a percentage of the separate $\mathrm{CD} 4^{+}$and $\mathrm{CD}^{+}$ subsets are shown in $(\mathbf{B})$ and proportions of each in $\mathrm{CD}^{+} \mathrm{T}$ cells as a whole $(\mathbf{C})$ are shown. $\mathrm{CD}_{103}{ }^{+} \mathrm{T}_{\mathrm{RM}}$, both $\mathrm{CD}^{+}$and $\mathrm{CD}^{+}$, were most frequent in the epidermis whereas CD103 ${ }^{-}$ $\mathrm{T}_{\mathrm{RM}}$, in both $\mathrm{CD}^{+}$and $\mathrm{CD}^{+} \mathrm{T}$ cells, were more frequent in the dermis. Recirculating $\mathrm{T}$ cells were the minority among both $\mathrm{CD}^{+}$and $\mathrm{CD}^{+} \mathrm{T}$ cell populations in skin. (D) $\mathrm{CD} 103^{+}$ $\mathrm{T}_{\mathrm{RM}}$ were superior to other $\mathrm{T}$ cell subsets in the production of effector cytokines. Shown are the relative production of the indicated effector cytokines by $\mathrm{CD}^{+} 9^{+} / \mathrm{CD} 103^{+}\left(\mathrm{CD} 103^{+}\right.$

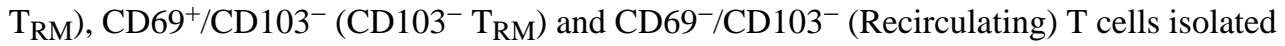
from healthy human skin. $T$ cell subsets were isolated from either non-fractionated skin (whole skin), the epidermis alone and the dermis alone. The mean and SEM of analyses from three donors (whole skin), and five donors (epidermis and dermis) are shown (test:one way ANOVA). 

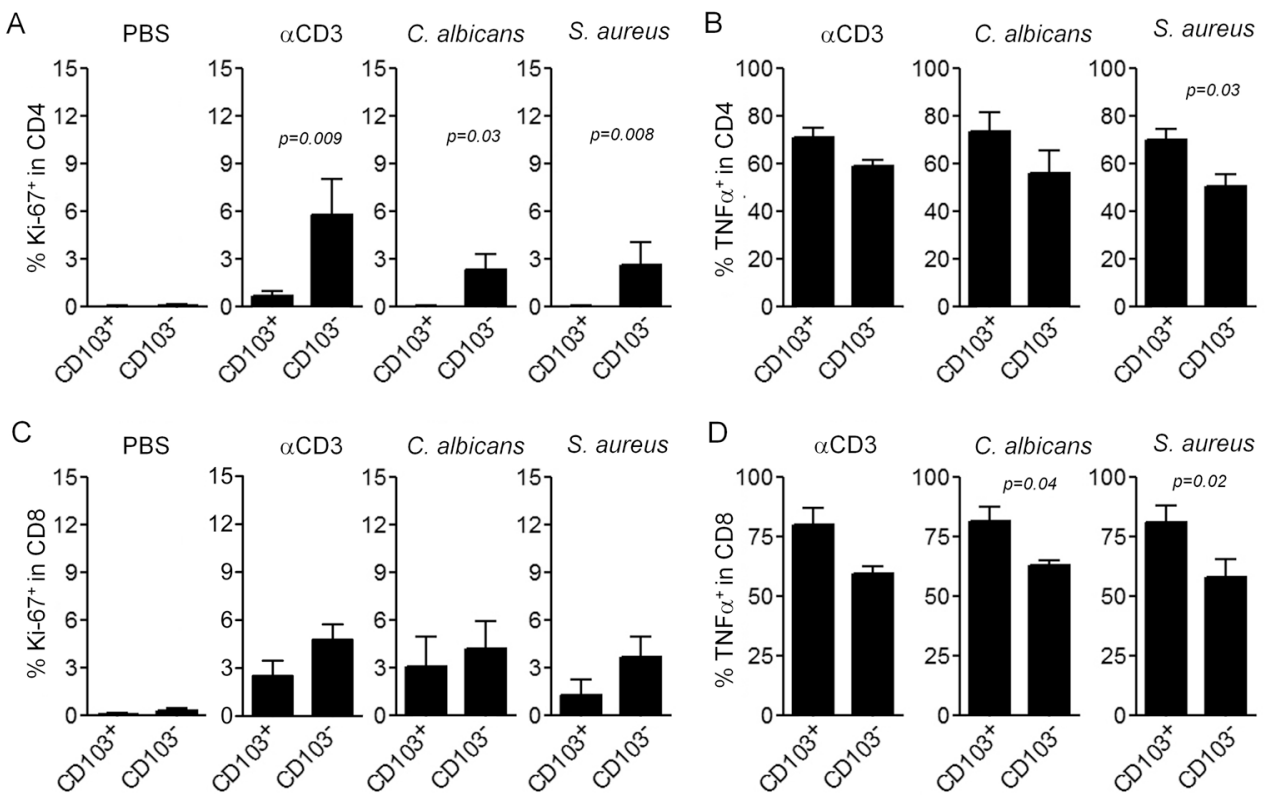

Figure 5. $\mathrm{CD103}^{+} \mathrm{T}_{\mathrm{RM}}$ have a lower proliferative capacity but increased effector function Skin explants were injected with PBS, stimulatory anti-CD3and anti-CD28 antibodies (aCD3), or heat killed extracts of $C$. albicans and S. aureus. Two weeks later, T cells that had migrated out of the skin were collected and the proliferation of $\mathrm{CD}^{+} \mathrm{T}_{\mathrm{RM}}(\mathbf{A})$ and $\mathrm{CD}^{+} \mathrm{T}_{\mathrm{RM}}(\mathbf{C})$ were assayed by staining for Ki-67 and flow cytometry analysis. TNFa production was assayed by intracellular cytokine staining and flow cytometry analysis after stimulation with PMA and ionomycin. Results for $\mathrm{CD}^{+} \mathrm{T}_{\mathrm{RM}}(\mathbf{B})$ and $\mathrm{CD}^{+} \mathrm{T}_{\mathrm{RM}}$ (D) are shown. Results are shown for $\mathrm{CD}^{+} 9^{+} / \mathrm{CD} 103^{+}\left(\mathrm{CD} 103^{+} \mathrm{T}_{\mathrm{RM}}\right)$, and $\mathrm{CD} 69^{+} / \mathrm{CD} 103^{-}$ $\left(\mathrm{CD} 103^{-} \mathrm{T}_{\mathrm{RM}}\right)$ The mean and SEM of three donors (PBS) and six donors (all other conditions) are shown (test:T-test). 

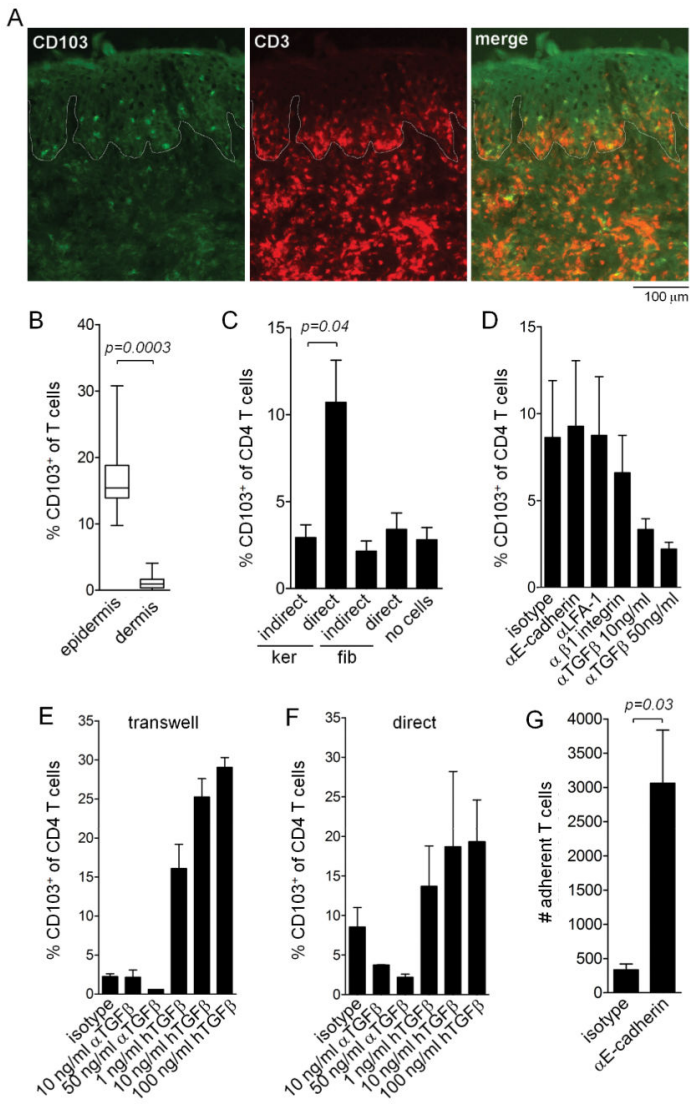

Figure 6. T cell CD103 induction is enhanced by keratinocyte contact, depends on TGF $\beta$ and is independent of $T$ cell keratinocyte adhesive interactions

$(\mathbf{A}, \mathbf{B})$ In human engrafted mice, $T$ cells that migrating into the epidermis had a higher rate of CD103 up-regulation than dermal T cells. (A) Representative immunostains of human foreskin skin grafts 3 weeks after IV injection of CD103- PBMC are shown. CD103 ${ }^{+}$T cells were primarily localized to the epidermal compartment. The dermal-epidemal junction is highlighted by a white line. (B) The mean and SEM of 8 separate experiments are shown (test: T-test). (C) Keratinocyte contact induced up regulation of CD103 in CD4 ${ }^{+} \mathrm{T}$ cells from human blood stimulated with $\mathrm{aCD} 3 / \mathrm{aCD} 2 / \mathrm{aCD} 28$ beads. $\mathrm{CD} 4^{+} \mathrm{T}$ cells were isolated from human peripheral blood by magnetic bead separation and then co-cultured in direct contact (direct) with confluent monolayers of human keratinocytes (ker) or fibroblasts (fib) or in transwells separated from keratinocyte or fibroblasts monolayers (indirect) for one week in the presence of $\mathrm{aCD} 3 / \mathrm{aCD} 2 / \mathrm{aCD} 28$ beads. CD103 expression was then assessed by immunostaining and flow cytometry anlysis. The mean and SEM of four separate experiments are shown (test: ANOVA). (D). Blocking of adhesive interactions with keratinocytes had no effect on CD103 upregulation but neutralization of TGF $\beta$ did decrease CD103 induction. $\mathrm{CD}^{+} \mathrm{T}$ cells were cultured on confluent human keratinocyte monolayers for one week in the presence of $\mathrm{aCD} 3 / \mathrm{aCD} 2 / \mathrm{aCD} 28$ beads and the indicated control and function blocking antibodies. The mean and SEM of four experiments are shown (test: ANOVA). (E,F) TGF $\beta$ neutralizing antibodies decreased and exogenous TGF $\beta$ increased CD103 induction. T cells were cultured in transwells across from keratinocyte monolayers (E) or indirect contact with keratinocyte monolayers (F) for one week in the presence of 
$\mathrm{aCD} 3 / \mathrm{aCD} 2 / \mathrm{aCD} 28$ beads and the indicated neutralizing TGF $\beta$ antibodies ( $\mathrm{aTGF} \beta$ ) or recombinant human TGF $\beta$ (hTGF $\beta$ ). the mean and SEM of 2 separate experiments are shown (test: ANOVA). (G) Function blocking E-cadherin antibodies inhibited T cell adhesion to keratinocyte monolayers. $\mathrm{CD} 4^{+} \mathrm{T}$ cells were cultured on confluent human keratinocyte monolayers for one week in the presence of $\mathrm{aCD} 3 / \mathrm{aCD} 2 / \mathrm{aCD} 28$ beads in the presence of isotype control or E-cadherin function blocking antibodies. Nonadherent $\mathrm{T}$ cells were removed by rinsing and adherent $\mathrm{T}$ cells were then eluted from the wells by treatment with trypsin/EDTA. The mean and SEM of the number of adherent cells per well from three separate experiments are shown (test:T-test). 

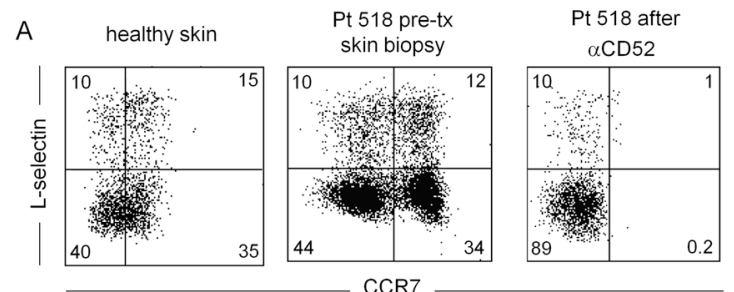

B
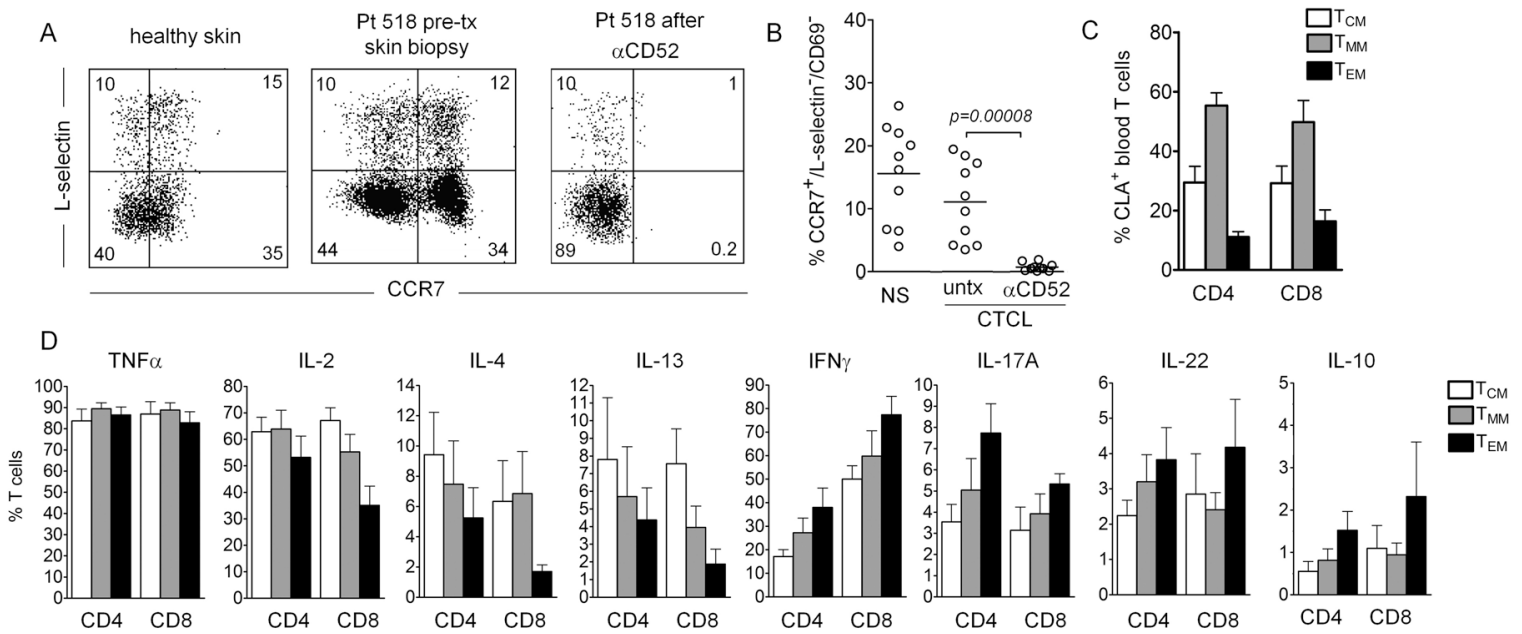

Figure 7. $\mathrm{CCR} 7^{+} / \mathrm{L}_{-}$selectin $^{-} \mathrm{T}$ cells make up a second distinct population of recirculating $\mathrm{T}$ cells in human skin

(A) $\mathrm{CCR}^{+} / \mathrm{L}$-selectin ${ }^{-} \mathrm{T}$ cells were present in healthy human skin and the skin of CTCL patients and were depleted by alemtuzumab therapy. (B) The proportion of $\mathrm{T}_{\mathrm{MM}}\left(\mathrm{CCR} 7^{+} / \mathrm{L}-\right.$ selectin $^{-} / \mathrm{CD}^{-} 9^{-} \mathrm{T}$ cells) in 10 healthy skin donors (NS) and ten CTCL patients before (untx) and after (aCD52) alemtuzumab therapy are shown (test: T-test). (C) $\mathrm{T}_{\mathrm{MM}}$ are the most frequent $\mathrm{CLA}^{+}$memory $\mathrm{T}$ cell population in human blood. The relative percentages of CCR7 ${ }^{+} / \mathrm{L}$-selectin ${ }^{+}$central memory $\left(\mathrm{T}_{\mathrm{CM}}\right), \mathrm{CCR} 7^{+} / \mathrm{L}$-selectin ${ }^{-}$migratory memory $\left(\mathrm{T}_{\mathrm{MM}}\right)$, and CCR7 ${ }^{-} / \mathrm{L}$-selectin ${ }^{-}$effector memory $\left(\mathrm{T}_{\mathrm{EM}}\right) \mathrm{T}$ cells in the $\mathrm{CD} 4^{+}$and $\mathrm{CD} 8^{+} \mathrm{T}$ cells from human peripheral blood are shown. The mean and SEM of four donors are shown.

Representative histograms are included in Fig. S4. (D) The effector functions of circulating $\mathrm{T}_{\mathrm{MM}}$ are intermediate between those of $\mathrm{T}_{\mathrm{CM}}$ and $\mathrm{T}_{\mathrm{EM}}$. For panels, $\mathrm{C}$ and $\mathrm{D}, \mathrm{T}$ cells were isolated from peripheral blood, stimulated with PMA and ionomycin in the presence of an Lselectin shedding inhibitor, stained for surface markers and intracellularly for cytokine production and then analyzed by CyTOF mass spectrometry. The mean and SEM of four donors are shown (test: ANOVA). 

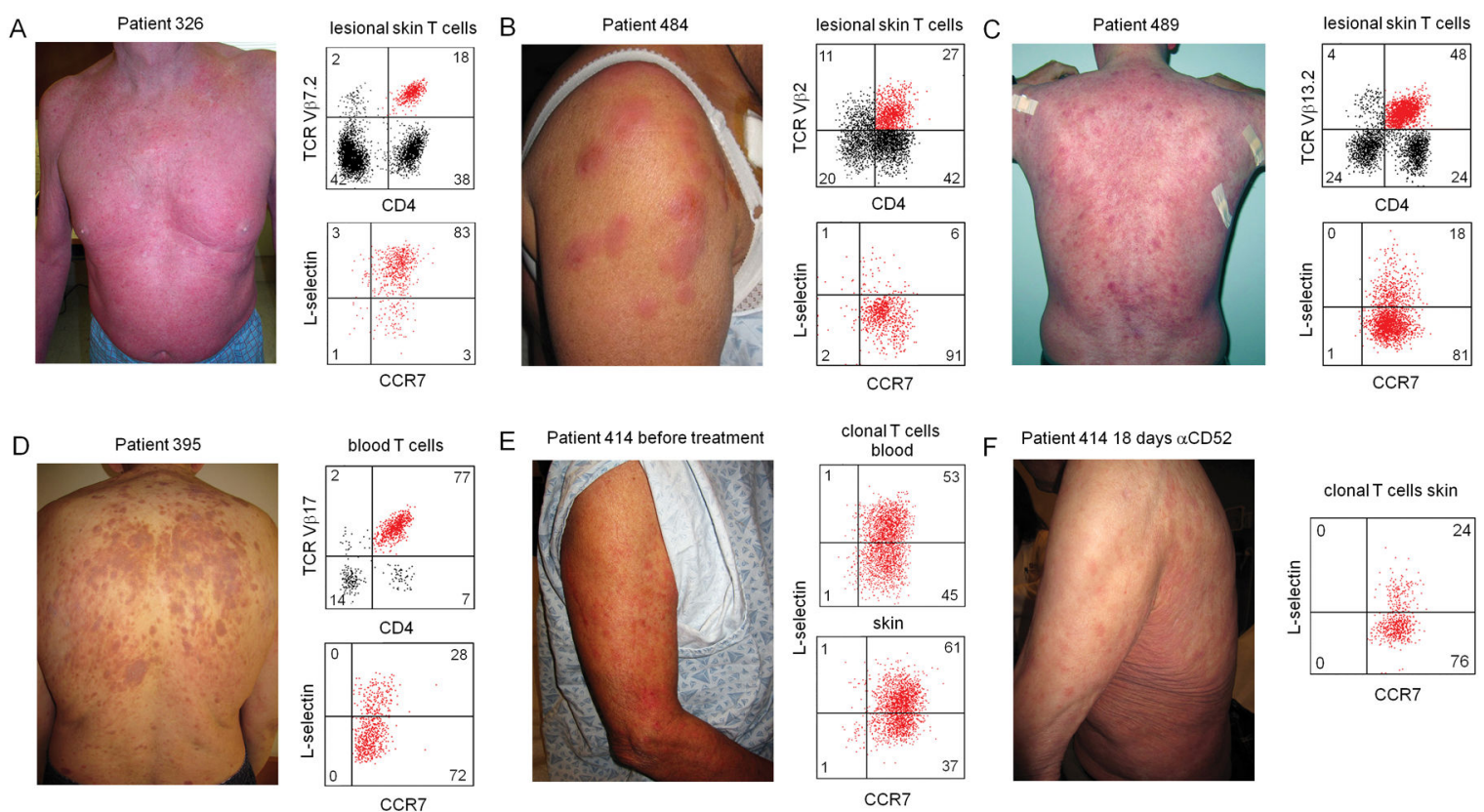
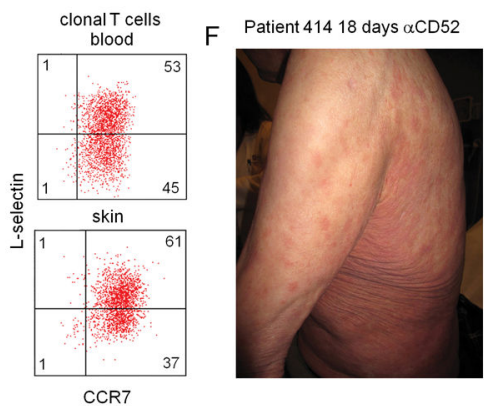

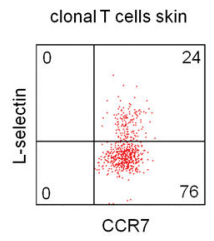

Figure 8. In human patients with CTCL, malignant $T$ cells with a $T_{M M}$ phenotype were associated with expanding skin lesions with ill-defined borders and were depleted more slowly from skin then $\mathbf{T}_{\mathbf{C M}}$ after alemtuzumab therapy

(A) CTCL patients with malignant $\mathrm{T}$ cells of a $\mathrm{T}_{\mathrm{CM}}\left(\mathrm{CCR} 7^{+} / \mathrm{L}\right.$-selectin $\left.{ }^{+}\right)$phenotype had diffuse erythema of the skin. In contrast, CTCL patients in whom the malignant $\mathrm{T}$ cells have a $\mathrm{T}_{\mathrm{MM}}$ phenotype $\left(\mathrm{CCR} 7^{+} / \mathrm{L}_{\text {-selectin }}{ }^{-}\right)$in lesional skin $(\mathbf{B}, \mathbf{C})$ or blood $(\mathbf{D})$, presented with expanding discrete skin lesions with ill-defined borders. (E) A patient who had malignant $\mathrm{T}$ cells of both $\mathrm{T}_{\mathrm{CM}}$ and $\mathrm{T}_{\mathrm{MM}}$ phenotype had both diffuse erythema on presentation as well as discrete skin lesions with ill-defined borders. The patient was placed on alemtuzumab therapy and the skin was re-biopsied 18 days later. (F) 18 days after alemtuzumab initiation, the discrete erythema had receded, leaving the ill-defined skin lesions. Analysis of T cells from the skin demonstrated a relative depletion of $\mathrm{T}_{\mathrm{CM}}$ but persistence of $\mathrm{T}_{\mathrm{MM}}$ in skin. 